\title{
MODEL MORFOLOŠKE IN SOCIALNOGEOGRAFSKE ZGRADBE URBANEGA PROSTORA NA PRIMERU CELJA, KOPRA IN PTUJA
}

\author{
Dejan Rebernik ${ }^{*}$
}

Izvleček

UDK 911.375.6=863(497.4)

$V$ prispevku je prikazan poskus oblikovanja modela mestne zgradbe na primeru treh srednje velikih slovenskih mest. Model je izdelan na osnovi analize morfološke in socialnogeografske zgradbe mesta ter prevladujoče rabe tal.

Ključne besede : Model mestne zgradbe, morfološka in socialnogeografska zgradba mesta, Celje, Koper, Ptuj.

A MODEL OF MORPHOLOGICAL AND SOCIOGEOGRAPHICAL STRUCTURE OF URBAN SPACE STUDIED AT CELJE, KOPER AND PTUJ

\section{Abstract}

An attempt is presented, of making a model of town structure, studied in three medium-sized Slovenian towns. This model has been made on the basis of analysing morphological and sociogeographical structure of town as well as the prevailing land use.

Key words: Town structure model; Morphological and sociogeographical structure of town; Celje; Koper; Ptuj.

\footnotetext{
* Mag., asistent, Oddelek za geografijo, Filozofska fakulteta Unoverze v Ljubljani, Aškerčeva 2, SI 1000 Ljubljana, Slovenija
} 


\section{UVOD}

V znanosti lahko model definiramo kot miselno ali matematična konstrukcijo, ki nadomešča oziroma predstavlja dejanski pojav. Osnovni cilj izdelave modelov je poenostavitev kompleksnosti proučevanega pojava, ob ohranitvi vseh osnovnih značilnosti in posebnosti le-tega. To nam omogoča, da pojave pojasnjujemo in napovedujemo. Izdelava modelov oziroma modeliranje je tako ena izmed osnovnih znanstvnih metod raziskovanja. Pri interpretaciji oziroma razlagi modela se moramo zavedati, da le-ta le relativno ustrezno ponazarja dejanski pojav in da so vse ugotovitve, do katerih pridemo s pomočjo znanstvenega modela le bolj ali manj ustrezne ocene dejanskega stanja.

$\mathrm{Za}$ čimbolj nazorno in splošno predstavitev kompleksne prostorske organizacije mest se $\mathrm{v}$ urbani geografiji pogosto uporablja takoimenovane modele mestne strukture. V njih so različni avtorji poskušali vključiti vse osnovne elemente notranje zgradbe mestnega prostora in odnose, ki te elemente povezujejo $\mathrm{v}$ mestni organizem. Takšen model mora po eni strani vsebovati vse bistvene poteze organizacije prostora $v$ mestu, pri tem pa mora biti čim bolj enostaven in splošen.

Modele prostorske organizacije mesta bi lahko razdelili v tri osnovne skupine (Bailly, 1975):

- opisni ali morfološki modeli, s katerimi ponazorimo vzorec prostorske organizacije mesta. V to skupino spadajo klasični modeli mestne strukture (Burgess, Hoyt...)

- eksplikativni modeli, s katerimi razložimo zakonitosti prostorske organizacije mesta. V ta namen se uporablja različne matematične in statistične modele (analitični, verjetnostni, simulacijski modeli...)

- normativni ali futuristični modeli, s katerimi predstavimo idealno oziroma optimalno prostorsko organizacijo mesta (npr. modeli vrtnih mest..)

Pri tem je potrebno opozoriti, da vsi modeli izhajajo iz predhodne analize opazovanega pojava in sinteze rezultatov v splošne ugotovitve. Ker pri analizi, ne glede na metode, ki jih pri tem uporabljamo, zajamemo oziroma opazujemo le določene vidike opazovanega pojava, je tudi model vedno le parcialna, delna predstavitev dejanskega stanja. To velja tudi v primeru modelov mestne strukture, ki lahko temeljijo na proučevanju rabe tal oziroma funkcijske zgradbe mesta, gostote prebivalstva, intenzivnosti rabe mestnega prostora in s tem povezanimi cenami zemljišč, morfološke ali socialnogeografske zgradbe mesta in podobno. Pogosto poskušajo avtorji v model vključiti več vidikov organizacije mestnega prostora in $\mathrm{s}$ tem doseči, da bi bil le-ta čimbolj celovit. 
V primeru naše raziskave smo poskušali izdelati model, ki naj vključuje in pojasnjuje izbrane značilnosti morfološke in socialnogeografske zgradbe mesta, $v$ manjši meri pa tudi obliko in intenzivnost rabe tal $\mathrm{v}$ mestu. Gre torej za parcialni model mestne zgradbe, zato smo ga poimenovali model morfološke in socialnogeografske zgradbe urbanega prostora.

Model sestavlja členitev mestnega prostora na homogena morfološkosocialnogeografska območja in povezava omenjenih območji v mestni organizem. Mesto pri tem obravnavamo kot prostorski sistem, elementi katerega so morfološkosocialnogeografska območja. Prostorski sistem predstavlja zbir elementov in njihovih medsebojnih odnosov in relacij. Gre torej za urejenost elementov v celoto, katere lastnosti niso le seštevek lastnosti posameznih elementov. V tem smislu sistem prostorske organizacije mesta predstavljajo elementi (morfološko-socialnogeografska območja), medsebojni odnosi (prostorska in funkcionalna medsebojna odvisnost, povezave, tudi nekompatibilnost - odbijanje, pozitivne in negativne povratne veze...) in povezanost elementov $\mathrm{v}$ obliki mesta kot celote.

\section{MODEL MORFOLOŠKE IN SOCIALNOGEOGRAFSKE ZGRADBE MESTA}

Izdelava modela morfolške in socialnogeografske zgradbe temelji na sintezi rezultatov do katerih smo prišli s pomočjo naslednjih metod proučevanja prostorske organizacije mestnega prostora :

- analize prostorske razporeditve posameznih elementov morfološke oziroma socialnogeografske zgradbe mesta,

- analize korelacijskih odnosov med posameznim spremenljivkami,

- primerjave socialnogeografske strukture posameznih morfoloških območij,

- proučevanja morfološke oziroma socialnogeografske zgradbe ob uporabi metode razvrščanja v skupine in faktorske analize. 
Karta 1: Celje - Model morfološke in socialnogeografske zgradbe

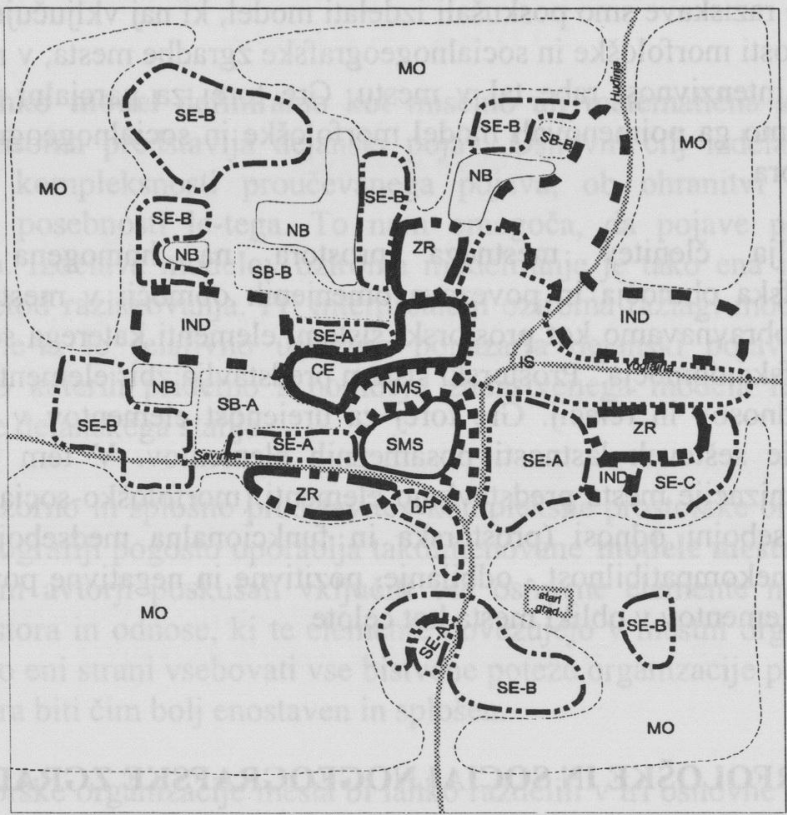

Karta 2: Koper - Model morfološke in socialnogeografske zgradbe

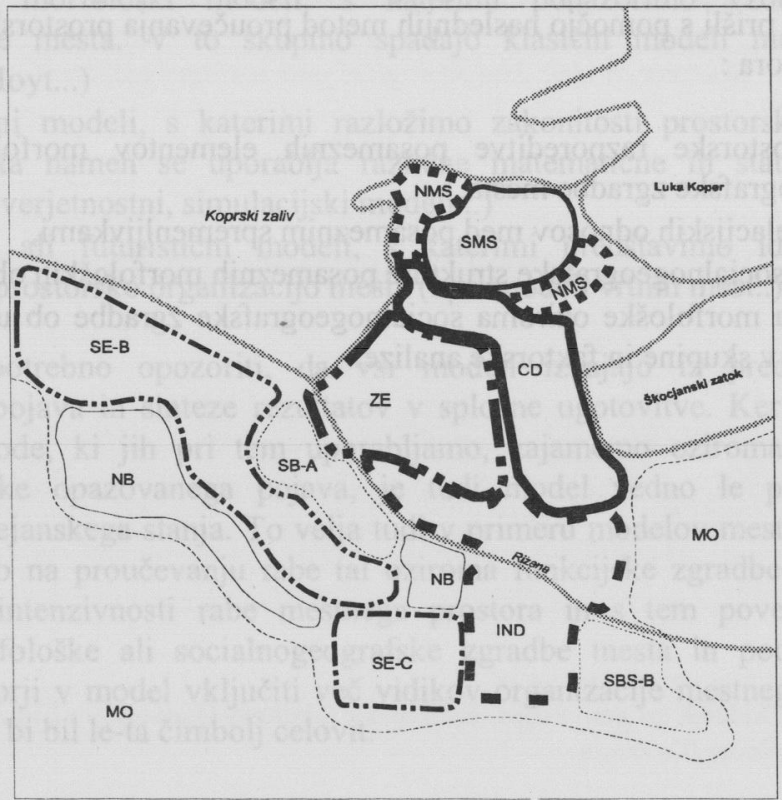


Karta 3: Ptuj - Model morfološke in socialnogeografske zgradbe

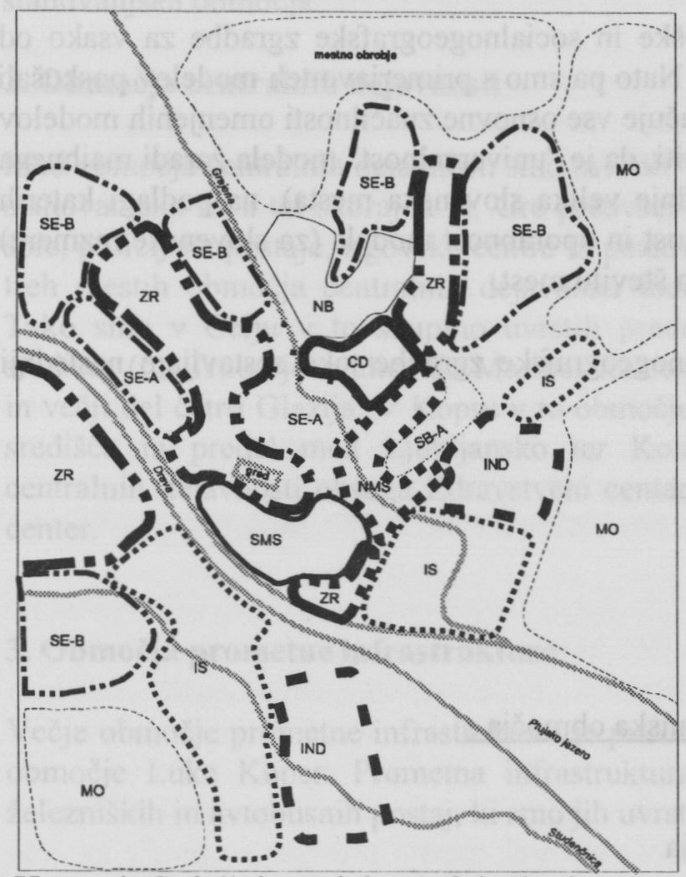

Karta 4: Splošni model morfološke in socialnogeografske zgradbe

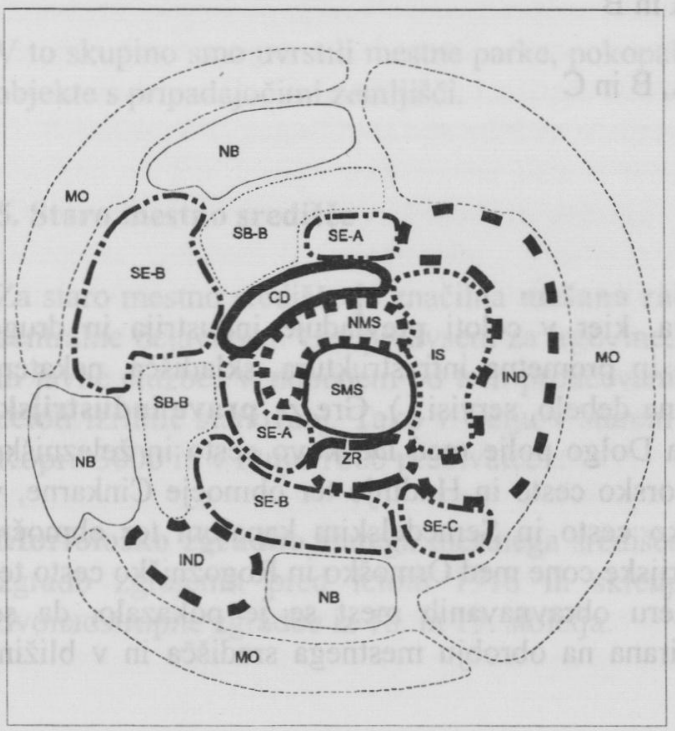

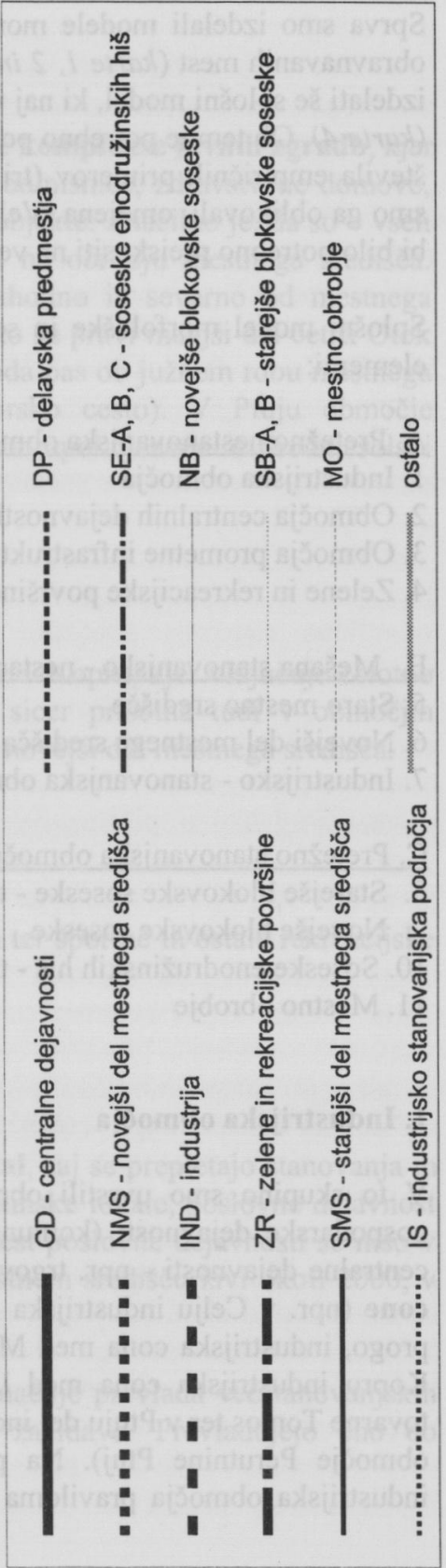


Sprva smo izdelali modele morfološke in socialnogeografske zgradbe za vsako od obravnavanih mest (karte 1, 2 in 3). Nato pa smo s primerjavo teh modelov poskušali izdelati še splošni model, ki naj vključuje vse osnovne značilnosti omenjenih modelov (karta 4). Ob tem je potrebno poudariti, da je "univerzalnost" modela zaradi majhnega števila empiričnih primerov (tri srednje velika slovenska mesta), na podlagi katerih smo ga oblikovali, omejena. Veljavnost in uporabnost modela (za slovenske razmere) bi bilo potrebno preiskusiti na večjem številu mest.

Splošni model morfološke in socialnogeografske zgradbe tako sestavljajo naslednji elementi:

\section{A. Pretežno nestanovanjska območja :}

1. Industrijska območja

2. Območja centralnih dejavnosti

3. Območja prometne infrastrukture

4. Zelene in rekreacijske površine

B. Mešana stanovanjsko - nestanovanjska območja :

5. Staro mestno središče

6. Novejši del mestnega središča

7. Industrijsko - stanovanjska območja

C. Pretežno stanovanjska območja :

8. Starejše blokovske soseske - tip A in B

9. Novejše blokovske soseske

10. Soseske enodružinskih hiš - tip A, B in C

11. Mestno obrobje

\section{Industrijska območja}

$\mathrm{V}$ to skupino smo uvrstili območja, kjer $\mathrm{v}$ celoti prevladuje industrija in druge gospodarske dejavnosti (komunalna in prometna infrastruktura, skladišča, nekatere centralne dejavnosti - npr. trgovina na debelo, servisi...). Gre za prave industrijske cone (npr. v Celju industrijska cona Dolgo polje med Dečkovo cesto in železniško progo, industrijska cona med Mariborsko cesto in Hudinjo ter območje Cinkarne, v Kopru industrijska cona med Istrsko cesto in Semedelskim kanalom ter območje tovarne Tomos ter v Ptuju del industrijske cone med Ormoško in Rogozniško cesto ter območje Perutnine Ptuj). Na primeru obravnavanih mest se je pokazalo, da so industrijska območja praviloma locirana na obrobju mestnega središča in v bližini 
železniške proge. Značilno je, da so $\mathrm{v}$ neposredni bližini industrijskih con stanovanjska območja.

\section{Območja centralnih dejavnosti}

Med območja centralnih dejavnosti smo uvrstili večje komplekse javnih zgradb, kjer stanovanjska raba tal skorajda ni. Gre predvsem za bolnišnice, zdravstvene domove, šole, policijske postaje, trgovske centre in poslovne objekte. Značilno je, da so v vseh treh mestih območja centralnih dejavnosti locirana na obrobju mestnega središča. Tako smo v Celju v to skupino uvrstili predel zahodno in severno od mestnega središča (od Trubarjeve ulice do Mariborske ceste), to se pravi manjši del četrti Otok in večji del četrti Glazija. V Kopru v to območje spada pas ob južnem robu mestnega središča in predel med Ljubljansko ter Kolodvorsko cesto). V Ptuju območje centralnih dejavnosti obsega Zdravstveni center, Dom upokojencev in Srednješolski center.

\section{Območja prometne infrastrukture}

Večje območje prometne infrastrukture je prisotno le v Kopru, kjer vključuje celotno območje Luke Koper. Prometna infrastruktura je sicer prisotna tudi v območjih železniških in avtobusnih postaj, ki smo jih uvrstili v novejši del mestnega središča.

\section{Zelene in rekreacijske površine}

V to skupino smo uvrstili mestne parke, pokopališča ter športne in ostale rekreacijske objekte s pripadajočimi zemljišči.

\section{Staro mestno središče}

Za staro mestno središče je značilna mešana raba tal, saj se prepletajo stanovanja in centralne dejavnosti. Gre predvsem za trgovine, gostinske lokale, poslovne dejavnost in javne službe. V nobenem od treh proučevanih mest poslovne dejavnosti še niso $\mathrm{v}$ celoti izrinile stanovanj. Tako v Celju v starem mestnem središču živi okoli 2000 , v Kopru 3000 in v Ptuju 1600 prebivalcev.

Morfološko zgradbo starega mestnega središča označuje prevlada večstanovanjskih zgradb zgrajenih pred letom 1918 in sklenjene zazidave. Prevladujejo eno do dvonadstropne zgradbe iz 18 . in 19. stoletja. 
Socialnogeografsko zgradbo starega mestnega središča označuje predvsem slab socioekonomski položaj in specifična starostna struktura prebivalstva ter struktura gospodinjstev. Slab socioekonomski položaj se kaže v slabi izobrazbeni strukturi (prevlada nižje izobraženih skupin prebivalstva), slabi poklicni strukturi (prevlada slabše plačanih skupin prebivalstva, predvsem storitvenih in industrijskih delavcev), slabi premoženjski strukturi, ki se kaže $\mathrm{v}$ nizkih dohodkih, visokem deležu nezaposlenih in tudi v zelo slabem stanovanjskem standardu (značilen je zelo visok delež stanovanj brez centralnega ogrevanja in stanovanj brez kopalnice). Za stara mestna središča je značilen tudi visok delež neslovenskega prebivalstva. Posebno slab socioekonomski položaj ima staro mestno središče v Ptuju, v nekoliko manjši meri pa v Celju. V Kopru so znotraj starega mestnega jedra opazne precejšne razlike. V manjšem delu starega mestnega središča je socioekonomski položaj prebivalstva precej ugodnejši (boljša izobrazbena struktura, višji dohodki, višji delež strokovnjakov...).Po vsej verjetnosti gre za tiste dele mestnega središča, ki so bili v zadnjem času obnovljeni in kot taki nudijo bistveno boljše bivanjske pogoje (predel okoli Trga Revolucije).

Drugi vidik socialnogeografske zgradbe, ki označuje staro mestno središče, pa je specifična starostna struktura prebivalstva in struktura gospodinjstev oziroma družinski status. Posebno močno izstopa visok delež samskih gospodinjstev in majhna povprečna velikost gospodinjstev, $v$ nekoliko manjši meri pa tudi nadpovprečno visok delež starejšega prebivalsta. Ob tem je zanimivo, da je tudi delež mlajšega prebivalstva relativno visok, $v$ vseh treh mestih presega povprečje za celo mesto. To lahko pripišemo dejstvu, da so se $v$ tem delu mesta zaradi nižje cene stanovanj oziroma najemnin naselile mlade družine $\mathrm{z}$ otroci. $\mathrm{Z}$ visokim deležem starejšega in pogosto samskega prebivalstva (predvsem vdove), pa je povezana tudi relativno velika stanovanjska površina na osebo. To si lahko pojasnimo s tem, da starejši prebivalci žive v relativno velikih družinskih stanovanjih, ki so jih zapustili odrasli otroci, kar lahko pojasnimo z majhno mobilnostjo starejšega prebivalstva.

\section{Novejši del mestnega središča .}

Kot posebno morfološko - socialnogeografsko območje smo izločili tisti del mestnega središča, za katerega je značilna heterogena morfološka zgradba. Tako je za ta del mesta značilno prepletanje starejših zgradb zgrajenih do leta 1918 z novejšimi stanovanjskimi bloki in stolpiči ter poslovnimi in drugimi javnimi zgradbami. Gre za nekdanje obrobje mestnega središča, ki je bilo pogosto pozidano $\mathrm{z}$ manjšimi in manj kvalitetnimi stanovanjskimi zgradbami. Tak morfološki tip je prisoten predvsem $\mathrm{v}$ Celju in v Kopru, v manjši meri pa tudi v Ptuju. Tudi za ta del mesta je značilno prepletanje centralnih dejavnosti (predvsem javne zgradbe, hoteli, trgovski in poslovni 
prostori) in stanovanj. V Celju živi v novejšem delu mestnega središča okoli 1500 , v Kopru 2300 in v Ptuju 600 prebivalcev.

Socialnogeografsko zgradbo tako omejenega območja označuje, za razliko od starega mestnega središča, relativno dober socioekonomski položaj prebivalstva, poleg tega pa še bolj izrazito kot $\mathrm{v}$ starem mestnem središču tudi prevlada starejšega prebivalstva in majhnih oziroma samskih gospodinjstev. Relativno ugoden socioekonomski položaj prebivalstva se kaže predvsem v dobri izobrazbeni strukturi (značilen je visok delež prebivalstva s srednjo oziroma višjo izobrazbo). Poklicna struktura prebivalstva ne odstopa bistveno od povprečja za celo mesto, nekoliko nadpovprečen je le delež strokovnjakov in upravnih delavcev. Tudi dohodki prebivalcev so nekoliko nadpovprečni. Iz tega lahko sklepamo, da v novejšem delu mestnega središča živi "srednji sloj". Visok delež višje izobraženih skupin prebivalstva pa kaže na koncentracijo intelektualcev v tistem delu mestnega središča, ki nudi boljše bivalne pogoje, kar se ujema $\mathrm{z}$ ugotovitvami večine sorodnih raziskav za zahodnoevropska mesta. Družinski status prebivalstva označuje majhna povprečna velikost gospodinjstev in visok delež samskih gospodinjstev ter nadpovprečen delež starejšega prebivalstva. Za ta del mesta so torej značilna majhna, pogosto samska in ostarela gospodinjstva. Tudi to dejstvo se ujema $\mathrm{z}$ ugotovitvami socialno - ekoloških raziskav.

\section{Industrijsko - stanovanjska območja}

Tretji morfološko - socialnogeografski tip, za katerega je značilno prepletanje stanovanjske in nestanovanjske rabe tal so industrijsko - stanovanjska območja. Povečini gre za starejše industrijske predele, kjer je poleg industrijskih objektov, skladišč in prometne infrastrukture tudi nekaj stanovanjskih zgradb. V Celju lahko govorimo o pravem delavskem predmestju (Gaberje), saj so bile stanovanjske zgradbe za delavce ob koncu 19. in $\mathrm{v}$ začetku 20. stoletja zgrajene skupaj $\mathrm{z}$ industrijskimi objekti, na kar kažejo tudi imena ulic v tem delu mesta (Tovarniška, Delavska, Kovinarska, Cinkarniška). Povečini gre za manjše večstanovanjske zgradbe v sklenjeni zazidavi. V industrijsko - stanovanjskih predmestjih Zavodna in Čret pa prevladujejo eno do dvostanovanjske hiše slabše kvalitete. V to skupino smo uvrstili tudi staro celjsko predmestje Breg. V Kopru takšnega morfološko socialnogeografskega območja zaradi specifičnega urbanističnega in gospodarskega razvoja mesta ni. V Ptuju je tipično delavsko predmestje $\mathrm{z}$ zgoraj naštetimi značilnostmi Breg na desnem bregu Drave ter novejši predel ob Rogozniški in Ormoški cesti.

Za industrijsko - stanovanjska območja so značilne zelo slabe ekološke in bivalne razmere (na kar kaže tudi zelo slab stanovanjski standard - delež stanovanj brez kopalnice dosega $30 \%$, brez centralnega ogrevanja pa $70 \%$ ), splošna zanemarjenost 
$\mathrm{Za}$ industrijsko - stanovanjska območja so značilne zelo slabe ekološke in bivalne razmere (na kar kaže tudi zelo slab stanovanjski standard - delež stanovanj brez kopalnice dosega $30 \%$, brez centralnega ogrevanja pa $70 \%$ ), splošna zanemarjenost in slaba kvaliteta zgradb. Vse to skupaj, z izrazito neugodno socialnogeografsko zgradbo, kaže na začetek socialne "getoizacije". V tako omejenih območjih živi v Celju okoli 1700, v Ptuju pa 900 prebivalcev.

Izrazito neugodna socialnogeografska zgradba je razvidna iz zelo slabe izobrazbene strukture prebivalstva (delež prebivalcev $\mathrm{z}$ nižjo izobrazbo praviloma presega $50 \%$ ), neugodne poklicne strukture (prevlada industrijskih in storitvenih delavcev), nizkih dohodkov prebivalstva (dohodnina na prebivalca dosega le okoli 75 $\%$ vrednosti za celo mesto) in visokega deleža nezaposlenih. Družinski status prebivalstva pa označuje prevlada majhnih oziroma samskih gospodinjstev. V povezavi z visokim deležem neslovenskega prebivalstva (v Celju skoraj $30 \%$ in na Bregu v Ptuju okoli 20 \%) lahko sklepamo, da je za ta del mesta značilnen visok delež priseljencev iz bivših republik Jugoslavije. Prevladujejo moški, ostali del družine je ostal "doma". Značilen je tudi posebno visok delež Albancev in Muslimanov ter relativno nižji delež Hrvatov in Srbov. Gre za specifično socialno skupino, za katero je značilen izrazito slab socioekonomski položaj, še posebno izstopa visoka nezaposlenost.

\section{Starejše blokovske soseske - tip A in B}

Med starejše blokovske soseske smo uvrstili območja, kjer prevladujejo stanovanjski bloki zgrajeni med leti 1946 in 1970. Povečini gre za štirinadstropne, prostostoječe bloke, v manjši meri tudi za posamezne višje stanovanjske stolpiče. V večini primerov ne moremo govoriti o pravih blokovskih soseskah z vso pripadajočo družbeno infrastrukturo (šola, oskrba, rekreacijske površine itd.), temveč bolj o skupinah večstanovanjskih zgradb. V starejših blokovskih soseskah živi v Celju okoli 9000, v Kopru 4000 in v Ptuju 1500 prebivalcev.

Tako določen morfološki tip pa smo na podlagi razlik v socialnogeografski zgradbi ločili na dve morfološko - socialnogeografski območji. Za tip A je značilen ugodnejši socioekonomski položaj prebivalstva. Ta se kaže $v$ relativno ugodni izobrazbeni strukturi, predvsem v visokem deležu prebivalcev s srednjo izobrazbo. Za poklicno strukturo je značilen nadpovprečen delež strokovnjakov in upravnih delavcev. 
Družinski status prebivalstva označuje predvsem nizek delež mlajšega prebivalstva, relativno majhna gospodinjstva, $v$ manjši meri pa tudi nadpovprečen delež starejšega prebivalstva. Iz tega lahko sklepamo, da $v$ tem delu mesta prevladujejo gospodinjstva srednje generacije. To lahko pojasnimo $\mathrm{z}$ dejstvom, da so ob izgradnji stanovanja kupile mlade družine, ki pa so se medtem postarale. Tudi ta proces je povezan tudi z majhno mobilnostjo prebivalcev v Sloveniji. Na splošno lahko rečemo, da po svoji socialnogeografski zgradbi starejše blokovske soseske tipa A v mnogočem spominjajo na novejši del mestnega središča, kar je prav gotovo povezano tudi z dejstvom, da so locirane v neposredni bližni mestnega središča.

Tip B starejših blokovskih sosesk se od tipa A loči po svoji socialnogeografski zgradbi, predvsem po socioekonomskem položaju prebivalstva, ki je nekoliko manj ugoden. Na splošno lahko rečemo, da socialnogeografska zgradba tega dela mesta ne odstopa od mestnega povprečja.

\section{Novejše blokovske soseske}

V to morfološko - socialnogeografsko območje smo uvrstili blokovske soseske zgrajene po letu 1971. Večinoma gre za večje soseske s spremljajočo družbeno infrastrkturo (šola, vrtec, oskrba, rekreacija...). Primer takšnih sosesk so npr. deli sosesk Zgornja Hudinja, Nova vas in Lava v Celju, soseska Podmarkovec v Kopru in del soseske Rabelčja vas v Ptuju. V novejših blokovskih soseskah živi v Celju okoli 15000, v Kopru 9000 in v Ptuju 5000 prebivalcev.

Socialnogeografsko zgradbo novejših blokovskih sosesk označuje predvsem specifična starostna struktura prebivalstva in struktura gospodinjstev. Tako ti deli mesta izstopajo po zelo visokem deležu mladega prebivalstva, nizkem deležu starejšega prebivalstva in velikih gospodinjstvih. Vse to kaže na prevlado mladih družin z otroci. Značilno je, da le-te žive $v$ relativno majhnih stanovanjih, na kar kaže majhna stanovanjska površina na osebo (pod $15 \mathrm{~m} 2$, v soseski Lava v Celju celo pod $10 \mathrm{~m} 2)$. $\mathrm{Za}$ socioekonomski položaj prebivalstva tega morfološko socialnogeografskega območja je značilno, da je relativno neugoden, čeprav precej boljši kot v starem mestnem središču ali stanovanjsko - industrijskih območjih. Izobrazbeno strukturo prebivalstva označuje nekoliko nadpovprečen delež prebivalcev $\mathrm{z}$ nižjo izobrazbo, poklicno strukturo pa visok delež industrijskih delavcev. Tudi dohodki prebivalcev so nekoliko podpovprečni (dohodnina na prebivalca dosega približno $95 \%$ vrednosti za celo mesto). Pri tem pa je potrebno opozoriti, da so med posameznimi soseskami in tudi znotraj sosesk glede socioekonomskega položaja prebivalstva precejšne razlike. Naslednja značilnost tega območja je nadpovprečen delež neslovenskega prebivalstva, ki v Celju dosega med 20 in $25 \%$, v Kopru med 30 in $35 \%$ ter v Ptuju okoli $10 \%$ prebivalstva. Predvidevamo, da gre ta tisti del 
neslovenskega prebivalstva, ki se je v Sloveniji "ustalil" in ustvaril družine. Ob tem je potrebno povdariti, da kljub nekoliko nižjemu deležu kot $v$ starem mestnem središču oziroma industrijsko - stanovanjskih območjih, v novejših blokovskih soseskah živi večji del neslovenskega prebivalstva ( $v$ Celju približno 3500 od skupaj 7500 in v Kopru 3000 od skupaj 7000).

\section{Soseske enodružinskih hiš - tip A, B in C}

Soseske enodružinskih hiš, za katere je značilna strnjena nesklenjena zazidava in prevlada eno oziroma dvostanovanjskih hiš, smo glede na razlike v socialnogeografski zgradbi razdelili $v$ tri tipe.

Tip A vključuje predvsem starejše soseske enodružinskih hiš, ki so praviloma locirane blizu mestnega središča. Značino je, da so te soseske začeli graditi že ob začetku stoletja. Glede na starost stanovanj so zato precej heterogene (stanovanja so deloma iz obdobja pred letom 1918, deloma iz časa med obema vojnama in deloma iz prvega povojnega obdobja). V večini primerov gre za območja z meščanskimi vilami, $v$ katerih je pred drugo svetovno vojno živel višji in srednji sloj prebivalstva. Opraviti imamo torej z tradicionalnimi elitnimi deli mesta. Med soseske enodružinskih hiš tipa A smo v Celju uvrstili del četrti Otok, sosesko Aljažev hrib, območje med Oblakovo ulico in železniško progo in osrednji del soseske Polule. V Ptuju v to skupino spadajo soseska Vičava in območje enodružinskih hiš med Maistrovo in Raičevo ulico ter Volkmerjevo cesto). V Kopru takšnega morfološko - socialnogeografskega tipa nismo določili.

Socialnogeografsko zgradbo tega dela mesta označujeta dve potezi : dober socioekonomski položaj prebivalstva in prevlada starejših ter manjših gospodinjstev. Dober socioekonomski položaj je razviden predvsem iz dobre izobrazbene strukture (delež prebivalcev z višjo izobrazbo praviloma presega $10 \%$ ). Pri poklicni strukturi izstopa visok delež strokovnjakov in vodilnih delavcev. Tudi dohodki prebivalcev so nadpovprečno visoki. Za družinski status pa je značilna prevlada starejših gospodinjstev in gospodinjstev srednje generacije. Razmeroma visok je tudi delež samskih gospodinjstev. Etnično strukturo zaznamuje nizek delež neslovenskega prebivalstva.

V tip B smo uvrstili večino preostalih sosesk enodružinskih hiš, za katere je značilno, da so bile zgrajene v povojnem obdobju. V času med leti 1946 in 1970 so bile zgrajene soseske enodružinskih hiš Zgornja Hudinja, Medlog in deloma Polule ter Zagrad v Celju, Semedela in deloma Žusterna ter Olmo v Kopru in soseska Štuki v Ptuju, po letu 1971 pa soseske enodružinskih hiš Lava, Ostrožno in Nova vas v Celju, Žusterna v Kopru in Nova vas, Orešje ter Rabelčja vas v Ptuju. Za zgoraj naštete 
novejše soseske enodružinskih hiš je značilno, da imajo najugodnejšo socioekonomsko sestavo prebivalstva od vseh območij. Ta se kaže v dobri izobrazbeni strukturi, visokem deležu strokovnjakov in vodilnih delavcev, visokih dohodkih prebivalcev (dohodnina na prebivalca dosega v Celju 130, v Kopru 140 in v Ptuju $120 \%$ vrednosti za celo mesto). Poleg tega je za novejše soseske enodružinskih hiš značilen nizek delež nezaposlenih in neslovenskega prebivalstva, prav tako pa tudi najugodnejši stanovanjski standard (stanovanjska površina na prebivalca dosega okoli $30 \mathrm{~m} 2$, delež stanovanj brez centralnega ogrevanja in stanovanj brez kopalnice pa je nizek). Podrobnejši pregled socioekonomskega položaja prebivalstva po posameznih soseskah pokaže, da je le-ta najugodnejši v soseskah zgrajenih po letu 1971 (npr. Lava in Ostrožno in Nova vas v Celju, del Semedele v Kopru in deli sosesk Orešje in Nova vas v Ptuju). Družinski status tega morfološko - socialnogeografskega območja ne odstopa bistveno od mestnega povprečja. Značilna je prevlada gospodinjstev srednje generacije in nizek delež samskih gospodinjstev. Iz podpovprečnega deleža prebivalstva do 18 leta starosti lahko sklepamo, da je delež mladih družin z otroci nizek. To pomeni, da si večina mladih družin ne more privoščiti "hiše z vrtom".

V tip C sosesk enodružinskih hiš smo uvrstili sosesko Podgorje v Celju in sosesko Olmo v Kopru, ki odstopata po slabem socioekonomskem položaju prebivalstva. Pri tem je potrebno povdariti, da se ti dve soseski precej razlikujeta.

Soseska Podgorje v Celju je primer soseske črnih gradenj. Gre za enodružinske hiše slabše kvalitete. Soseska se nahaja v delu mesta s slabimi ekološkimi razmerami (nad Celjsko Cinkarno) in močno degradiranim okoljem. V celoti daje ta del mesta vtis precejšnje neurejenosti. Socialnogeografsko zgradbo te soseske označuje izrazito slab socioekonomski položaj prebivacev, visok delež neslovenskega prebivalstva in prevlada velikih in mlajših gospodinjstev. Slab socioekonomski položaj se kaže v zelo slabi izobrazbeni strukturi prebivalstva (delež prebivalcev z nižjo izobrazbo dosega 60 $\%$ ), prevladi industrijskih delavcev (nad $50 \%$ ), nizkih dohodkih prebivalstva (dohodnina na prebivalca dosega le $65 \%$ vrednosti za celo mesto) in visokem deležu nezaposlenih. Delež neslovenskega prebivalstva dosega $40 \%$. Zelo slab je tudi stanovanjski standard, ki se kaže v majhni stanovanjski površini na osebo (pod $20 \mathrm{~m} 2$ ) in visokem deležu stanovanj brez centralnega ogrevanja ter stanovanj brez kopalnice. Za družinski status je značilna prevlada velikih ter mlajših gospodinjstev oziroma gospodinjstev srednje generacije. Gre torej za socialno zelo problematični del mesta, pri katerem bi lahko govorili o začetku "getoizacije".

Večji del soseske Olmo obsega manjše vrstne enodružinske hiše v neposredni bližini tovarne Tomos. Po socialnogeografski zgradbi, za katero je značilen podpovprečen, vendar ne izrazito slab socioekonmoski položaj prebivalcev, ta soseska spominja na starejše blokovske soseske tipa B (npr. Nova Šalara v Kopru). Predvsem izstopa slaba izobrazbena struktura in visok delež industrijskih delavcev, dočim dohodki 
prebivalcev niso dosti nižji od mestnega povprečja. Za stanovanjski standard je značilna predvsem nizka stanovanjska površina na osebo (pod $20 \mathrm{~m} 2$ ). Družinski status pa označuje prevlada nadpovprečno velikih gospodinjstev mlajše in srednje generacije.

\section{Mestno obrobje}

V morfološko - socialnogeografski tip mestno obrobje smo uvrstili območja na robu mesta, za katera je značilna redkejša oziroma nestrnjena zazidava. V celoti prevladujejo prostostoječe enodružinske hiše. Poleg stanovanjskih območij velik del ozemlja obsegajo agrarne površine in gozd. Zato je tudi gostota prebivalstva $\mathrm{v}$ tem delu mesta za urbana območja zelo nizka, saj praviloma ne presega 2 preb./ha.

V mestno obrobje so vključena predvsem nekoč samostojna ruralna naselja, ki pa so bila $s$ širjenjem mesta vključena $v$ urbano območje. $V$ središču teh naselij so stara vaška jedra $\mathrm{z}$ značilno vaško fiziognomijo (kmečke hiše in gospodarska poslopja, nepravilen tloris prometnic). Na obrobju, pa tudi med starejšimi zgradbami, je prišlo tudi do novejše gradnje enodružinskih hiš. To je razvidno iz podatkov o strukturi stanovanj po obdobju gradje (približno ena četrtina do leta 1918, četrtina med leti 1946 in 1970 in tretjina po letu 1971). Značilno je, da so ta naselja med seboj ločena z vmesnimi nepozidanimi površinami (agrarne površine ali gozd). V to skupino lahko v Celju uvrstimo obmestna naselja Spodnja Hudinja, Trnovlje, starejši del Zgornje Hudinje, Lopata, Babno in Ložnica, v Kopru Škocjan in v Ptuju obmestna naselja Spuhlja, Budina, Brstje, Rogoznica, del Spodnje Hajdine in Turnišče. Kot poseben tip mestnega obrobja pa bi lahko izločili območja $\mathrm{z}$ razloženo oziroma nesklenjeno zazidavo in zelo nizko gostoto prebivalstva (okoli 1 preb./ha). Gre predvsem za gričevnato oziroma hribovito obrobje mesta, kjer večji del površin zavzema gozd. V to skupino smo uvrstili Lisce, Miklavžev hrib, Stari grad in Zavodno v Celju, Markovec v Kopru in Mestni vrh v Ptuju.

Mestno obrobje ima zelo specifično socialnogeografsko zgradbo. Socioekonomski položaj prebivalstva, ki je relativno slab, označuje predvsem visok delež kmetijskih delavcev ( v Celju 12, v Kopru 8 in v Ptuju $16 \%$ aktivnega prebivalstva), ki je v ostalih delih mesta zelo nizek (pod $1 \%$ ). To kaže na polruralni značaj tega dela mesta. Najvišji delež sicer odpade na industrijske delavce (med 40 in $50 \%$ ). Značilna je tudi zelo slaba izobrazbena struktura (delež prebivalcev z nižjo izobrazbo presega $50 \%$ ) in podpovprečni dohodki prebivalcev (vendar ne izrazito nizki, dohodnina na prebivalca dosega okoli $90 \%$ mestnega povprečja). $\mathrm{V}$ primeru Celja in Ptuja močno izstopa tudi nizek delež neslovenskega prebivalstva (7 oziroma $6 \%$ ) in nizek delež nezaposlenih. Družinski status tega območja označuje prevlada velikih gospodinjstev. Starostna 
struktura pa kaže na enakomerno zastopanost vseh starostnih skupin prebivalstva. Iz tega lahko sklepamo, da so $\mathrm{v}$ tem delu mesta pogosta takoimenovana generacijska gospodinjstva, ki jih sestavljajo stari starši, starši in otroci.

\section{ZAKLJUČEK}

Osnovno izhodišče našega raziskovanja je bilo, da je tudi v slovenskih mestih prisotna diferenciacija mestnega prostora glede na morfološko in socialnogeografsko zgradbo.. Nadalje smo predvidevali, da obstaja med morfološko in socialnogeografsko zgradbo mesta določena povezanost in soodvisnost.

Obe zastavljeni delovni hipotezi lahko na podlagi opravljenih analiz in sintezi le-teh v model morfološke in socialnogeografske zgradbe potrdimo. Iz opisanega modela je namreč razvidno, da je prostorska socialna diferenciacija mestega prebivalstva prisotna tudi $v$ slovenskih mestih. Primerjava s sorodnimi študijami pokaže, da je stopnja te diferenciacije primerljiva $\mathrm{z}$ razmerami $\mathrm{v}$ manjših in srednjevelikih zahodnoevropskih mestih.

Potrdimo lahko tudi obstoj povezave med morfološko in socialnogeografsko zgradbo mesta. Tako je za določen morfološki tip mesta praviloma značilna specifična socialnogeografska zgradba. Ob tem je potrebno opozoriti, da "ujemanje" med obema vidikoma notranje zgradbe mesta, nikakor ni popolno. Tako so znotraj podobnih morfoloških območij (npr. soseske enodružinskih hiš ali blokovske soseske) precejšnje razlike v socialni sestavi prebivalstva, po drugi strani pa imajo nekatera povsem različna morfološka območja (npr. novejši del mestnega središča in blokovske soseske) določene skupne poteze.

Iz rezultatov naše raziskave lahko zaključimo, da socialnogeografsko zgradbo slovenskih mest sestavljata dva osnovna elementa : socioekonomska in družinska diferenciacija prebivalstva. Pri tem socioekonomsko difereciacijo določajo predvsem izobrazbena, poklicna in premoženjska struktura, družinsko pa struktura gospodinjstev in starostna struktura prebivalstva. Etnična sestava prebivalstva se sicer po posameznih delih mesta pomembno razlikuje, vendar ne $\mathrm{v}$ takšni meri, da bi samostojno določala oziroma označevala posamezne dele mesta. Ena izmed osnovnih ugotovitev faktorske ekologije je tudi dejstvo, da prostorska razporeditev posameznih skupnih faktorjev (socioekonomski, družinski in etnični status), sledi določenim zakonitostim. Tako je socioekonomski faktor razporejen sektorsko, družinski koncentrično in etnični večjedrno. To velja tudi v primeru Celja in Ptuja, v manjši meri pa v primeru Kopra. Območja z dobrim socioekonomski položajem so v Celju in Ptuju razporejena v obliki krakov oziroma sektorjev (npr. Otok-Medlog, Dolgo polje- 
Nova vas, Lava-Ostrožno, Aljažev hrib-Polule-Zagrad, Rabeljčja vas-Nova vas, Vičava--Orešje). Med njimi so območja s slabim oziroma povprečnim socioekonomskim položajem. Družinski status pa je razporejen v obliki koncentričnih krogov, ki se od mestnega središča širijo proti obrobju mesta. Tako je za notranja območja bliže mestnemu središču značilna prevlada majhnih in samskih gospodinjstev, starejšega prebivalstva in stanovanj v večstanovanjskih hišah. Proti obrobju mesta pa se povečuje povprečna velikost gospodinjstev, delež mladega prebivalstva in delež stanovanj $v$ enodružinskih hišah. Etnični status, ki je deloma prisoten le v Celju, ima dejansko več "središč" z visokimi vrednostmi (mestno središče, Gaberje, novejše blokovske soseske), tako da bi lahko govorili o večjederni prostorski razporeditvi. Kot je bilo rečeno, so v primeru Kopra opisani vzorci prostorske razporeditve manj očitni, kar je po vsej verjetnosti predvsem posledica specifičnih reliefnih razmer in urbanističnega razvoja mesta.

\section{LITERATURA}

- Bašić K.,1994 : Socijalno-prostorna segregacija stanovništva Zagreba. Geografski Horizont, broj 2, Godina XL, Zagreb.

- Bailly A., Beaudry M.,1976 : Analyse typologiques en milieu urbain : Les aires homogenes d'Edmonton (Canada). L'Espace géographiques, no.4, str. 267-275, Paris.

- Beaujeu-Garnier J., 1980 : Géographie urbaine. Armand Collin, Paris.

- Berger M., Debol-Kritter A., 1989 : Das Ortsbild von Augsburg. Angewandte Socialgeographie Beitrage, no. 19, Universität Augsburg.

- Drozg V., 1995 : Morfologija vaških naselij v Sloveniji. Geographica Slovenica 27, Ljubljana.

- Drozg V., 1990 : Členitev mestnega območja Izole, 15. Zborovanje slovenskih geografov. Portorož. Zveza geografskih društev Slovenije, Ljubljana.

- Geographia Polonica - The Urban Population at a Microscale, 1993. Polish Academy of Sciences, Institute of Geography and Spatial Organization, Warszawa.

- Hamm B., 1984 : Aktuelle Probleme sozialekölogischer Analyse. Koelner Zeitschrift fur Sociologie und Socialpsychologie, 36, 2.

- Klemenčič M. M., 1993 : Narodnostna in starostna sestava prebivalcev Tržiča, Geografski vestnik, 65, str. 79-90, Ljubljana.

- Klinar P., 1986 : Problematika medetničnih odnosov. RI FSPN. Ljubljana.

- Loboda J., 1989 : Ausgewählte Probleme der räumlichen Gliederung Wroclaws. Geographische Zeitschrift, 77. Jahrhang, Heft 4. 
- Lentz S., 1991 : Strukturraumanalyse und Stadtmodele. Überlegungen zu neuen Arbeitsansatzen am Beispiel der Stadt Mannhein. Studien zur Bevölkerungs- und Sozialgeographie, Mannheimer Geographischer Arbeiten, Mannheim.

- Maribor - Marburg, 1994 : Prispevek h geografiji prijateljskih mest. Maribor.

- Pak M., 1987 : Problematika izrabe mestnega prostora v Mariboru. Zbornik žII. kongresa geografa Jugoslavije u Vojvodini - 1985, Novi Sad.

- Pak M. , 1991 : Elementi demografskega razvoja v zgradbi Maribora. Dela 8, Ljubljana.

- Rebernik D., 1996 : Morfološka in socialnogeografska zgradba slovenskih mest (na izbranih primerih). Magistrska naloga, Oddelek za geografijo Filozofske fakultete v Ljubljani

- Schaffer F., Guttler H., 1982 : Sozialtopographie der Altstadt. Angewandete Sozialgeographie Beitrage, no. 4, Universität Augsburg.

- Seger M., Wastl-Walter D., 1991 : Die Socialistische Stadt in Mitteleuropa. Der Modellfall Halle a.d. Salle. Zustand und Struktur am Ende einer Epoche. Geographische Rundschau.

- Seger M., 1988 : Die Stadtstrucktur von Villach - Eine statistische Analyse nach Zahlbezircken. Stadt und Umwelt - Arbeiten zum Grünraumsituation in Villach. Villach.

- Toš N., 1986 : Socialna struktura sodobne slovenske družbe. RI FSPN, Ljubljana. 


\section{A MODEL OF MORPHOLOGICAL AND SOCIOGEOGRAPHICAL STRUCTURE OF URBAN SPACE STUDIED AT CELJE, KOPER AND PTUJ}

\section{Summary}

A basic premise of our investigation is that differentiation of urban space as to the morphological and sociogeographical structures is also present in Slovenian towns. Next, we assume that certain connectedness and interdependence exist between the morphological and sociogeographical structures of town.

Both working hypotheses can be confirmed on the basis of performed analyses and their synthesis into a model of morphological and sociogeographical structures. Namely, it is evident from the described model that the spatial social differentiation of urban population is present in Slovenian towns, too. A comparison with similar studies shows that the level of this differentiation is comparable to the conditions in minor and medium-sized western-European towns.

The existence of links between morphological and sociogeographical structures of town can also be confirmed. Thus, typical of a certain morphological type of town, as a rule, is the specific sociogeographical structure. On this point, attention should be called to the fact that the parallelism of both aspects of the inner structure of town is not perfect at all. Thus, within similar morphological areas (e.g. detached house districts or apartment house districts) rather great differences are evident in the social structure of the population, while on the other hand, certain areas which are morphologically totally different (e.g. newer parts of inner city and apartment house districts) have the common features.

We can conclude from the results of our investigation that the sociogeographical structure of Slovenian towns consists of two basic elements: the socioeconomic differentiation and the family differentiation of the population. Socioeconomic differentiation is determined especially by the educational, vocational and wealthrelated structures, while the family differentiation is determined by the structure of households and the age structure of the population. Although ethnic composition of the population significantly differs in the individual parts of town, yet, this differentiation is not so typical that it could determine or mark the individual parts of town.

Among the basic findings of factors' ecology is undoubtedly ranked the fact that the spatial distribution of individual common factors (socioeconomic, ethnic and the family status) is subject to certain laws. Thus, the socioeconomic factor is distributed 
in sectors, the family factor is distributed concentrically, and the ethnic factor occurs as the multicore distribution. This also applies to Celje and Ptuj, and in a smaller extent, to Koper. The areas of favourable socioeconomic position in Celje and Ptuj are distributed in the form of branches or sectors (e.g. Otok-Medlog, Dolgo polje-Nova vas, Lava-Ostrožno, Aljažev hrib-Polule-Zagrad, Rabeljčja vas-Nova vas, VičavaOrešje). In between them are the areas of poor or average socioeconomic position.

The family status is distributed in the form of concentric circles, which spread outwards from the town core to the suburbs. Thus, the inner areas which are closer to the town core, are typical of prevailing small or single households, elderly population and the apartment house housing. Towards the suburbs, the following factors increase: the average size of households, the percentage of young population, and the percentage of detached house housing. Ethnic status which is partly present only at Celje, has several "centers", in fact, with high values (the inner city, Gaberje, newer apartment house districts) so that it could be defined as the multicore spatial distribution. As mentioned above, the described examples of spatial distribution are less evident in Koper, which is most probably the result of specific conditions as to the landforms, and the town planning of Koper. 


\title{
MODEL MORFOLOŠKE IN SOCIALNOGEOGRAFSKE ZGRADBE URBANEGA PROSTORA NA PRIMERU CELJA, KOPRA IN PTUJA
}

\author{
Dejan Rebernik ${ }^{*}$
}

Izvleček

UDK 911.375.6=863(497.4)

$V$ prispevku je prikazan poskus oblikovanja modela mestne zgradbe na primeru treh srednje velikih slovenskih mest. Model je izdelan na osnovi analize morfološke in socialnogeografske zgradbe mesta ter prevladujoče rabe tal.

Ključne besede : Model mestne zgradbe, morfološka in socialnogeografska zgradba mesta, Celje, Koper, Ptuj.

A MODEL OF MORPHOLOGICAL AND SOCIOGEOGRAPHICAL STRUCTURE OF URBAN SPACE STUDIED AT CELJE, KOPER AND PTUJ

\section{Abstract}

An attempt is presented, of making a model of town structure, studied in three medium-sized Slovenian towns. This model has been made on the basis of analysing morphological and sociogeographical structure of town as well as the prevailing land use.

Key words: Town structure model; Morphological and sociogeographical structure of town; Celje; Koper; Ptuj.

\footnotetext{
* Mag., asistent, Oddelek za geografijo, Filozofska fakulteta Unoverze v Ljubljani, Aškerčeva 2, SI 1000 Ljubljana, Slovenija
} 


\section{UVOD}

V znanosti lahko model definiramo kot miselno ali matematična konstrukcijo, ki nadomešča oziroma predstavlja dejanski pojav. Osnovni cilj izdelave modelov je poenostavitev kompleksnosti proučevanega pojava, ob ohranitvi vseh osnovnih značilnosti in posebnosti le-tega. To nam omogoča, da pojave pojasnjujemo in napovedujemo. Izdelava modelov oziroma modeliranje je tako ena izmed osnovnih znanstvnih metod raziskovanja. Pri interpretaciji oziroma razlagi modela se moramo zavedati, da le-ta le relativno ustrezno ponazarja dejanski pojav in da so vse ugotovitve, do katerih pridemo s pomočjo znanstvenega modela le bolj ali manj ustrezne ocene dejanskega stanja.

$\mathrm{Za}$ čimbolj nazorno in splošno predstavitev kompleksne prostorske organizacije mest se $\mathrm{v}$ urbani geografiji pogosto uporablja takoimenovane modele mestne strukture. V njih so različni avtorji poskušali vključiti vse osnovne elemente notranje zgradbe mestnega prostora in odnose, ki te elemente povezujejo $\mathrm{v}$ mestni organizem. Takšen model mora po eni strani vsebovati vse bistvene poteze organizacije prostora $v$ mestu, pri tem pa mora biti čim bolj enostaven in splošen.

Modele prostorske organizacije mesta bi lahko razdelili v tri osnovne skupine (Bailly, 1975):

- opisni ali morfološki modeli, s katerimi ponazorimo vzorec prostorske organizacije mesta. V to skupino spadajo klasični modeli mestne strukture (Burgess, Hoyt...)

- eksplikativni modeli, s katerimi razložimo zakonitosti prostorske organizacije mesta. V ta namen se uporablja različne matematične in statistične modele (analitični, verjetnostni, simulacijski modeli...)

- normativni ali futuristični modeli, s katerimi predstavimo idealno oziroma optimalno prostorsko organizacijo mesta (npr. modeli vrtnih mest..)

Pri tem je potrebno opozoriti, da vsi modeli izhajajo iz predhodne analize opazovanega pojava in sinteze rezultatov v splošne ugotovitve. Ker pri analizi, ne glede na metode, ki jih pri tem uporabljamo, zajamemo oziroma opazujemo le določene vidike opazovanega pojava, je tudi model vedno le parcialna, delna predstavitev dejanskega stanja. To velja tudi v primeru modelov mestne strukture, ki lahko temeljijo na proučevanju rabe tal oziroma funkcijske zgradbe mesta, gostote prebivalstva, intenzivnosti rabe mestnega prostora in s tem povezanimi cenami zemljišč, morfološke ali socialnogeografske zgradbe mesta in podobno. Pogosto poskušajo avtorji v model vključiti več vidikov organizacije mestnega prostora in $\mathrm{s}$ tem doseči, da bi bil le-ta čimbolj celovit. 
V primeru naše raziskave smo poskušali izdelati model, ki naj vključuje in pojasnjuje izbrane značilnosti morfološke in socialnogeografske zgradbe mesta, $v$ manjši meri pa tudi obliko in intenzivnost rabe tal $\mathrm{v}$ mestu. Gre torej za parcialni model mestne zgradbe, zato smo ga poimenovali model morfološke in socialnogeografske zgradbe urbanega prostora.

Model sestavlja členitev mestnega prostora na homogena morfološkosocialnogeografska območja in povezava omenjenih območji v mestni organizem. Mesto pri tem obravnavamo kot prostorski sistem, elementi katerega so morfološkosocialnogeografska območja. Prostorski sistem predstavlja zbir elementov in njihovih medsebojnih odnosov in relacij. Gre torej za urejenost elementov v celoto, katere lastnosti niso le seštevek lastnosti posameznih elementov. V tem smislu sistem prostorske organizacije mesta predstavljajo elementi (morfološko-socialnogeografska območja), medsebojni odnosi (prostorska in funkcionalna medsebojna odvisnost, povezave, tudi nekompatibilnost - odbijanje, pozitivne in negativne povratne veze...) in povezanost elementov $\mathrm{v}$ obliki mesta kot celote.

\section{MODEL MORFOLOŠKE IN SOCIALNOGEOGRAFSKE ZGRADBE MESTA}

Izdelava modela morfolške in socialnogeografske zgradbe temelji na sintezi rezultatov do katerih smo prišli s pomočjo naslednjih metod proučevanja prostorske organizacije mestnega prostora :

- analize prostorske razporeditve posameznih elementov morfološke oziroma socialnogeografske zgradbe mesta,

- analize korelacijskih odnosov med posameznim spremenljivkami,

- primerjave socialnogeografske strukture posameznih morfoloških območij,

- proučevanja morfološke oziroma socialnogeografske zgradbe ob uporabi metode razvrščanja v skupine in faktorske analize. 
Karta 1: Celje - Model morfološke in socialnogeografske zgradbe

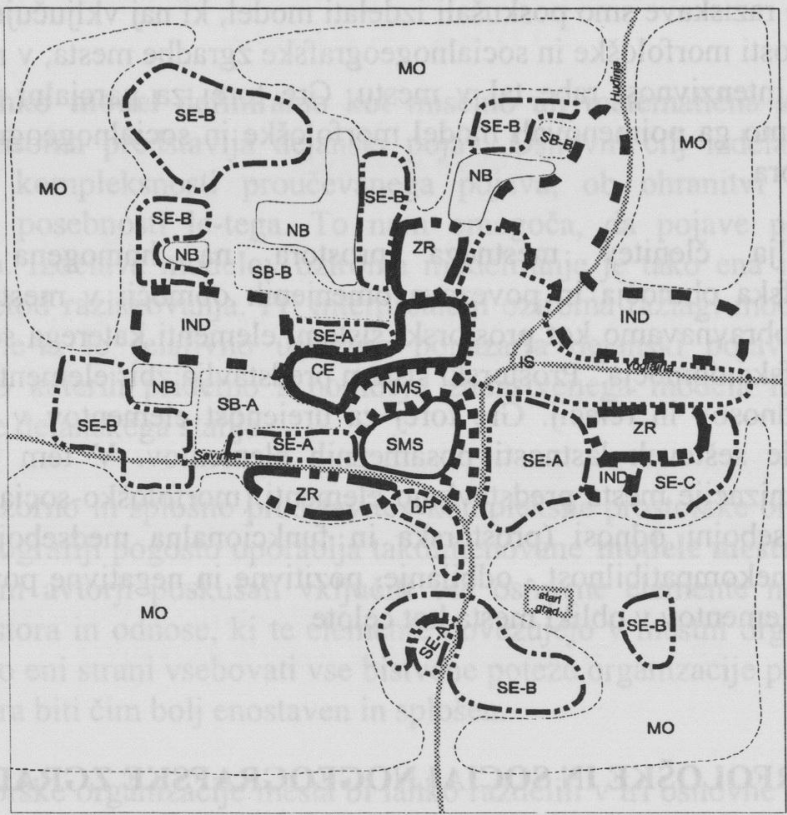

Karta 2: Koper - Model morfološke in socialnogeografske zgradbe

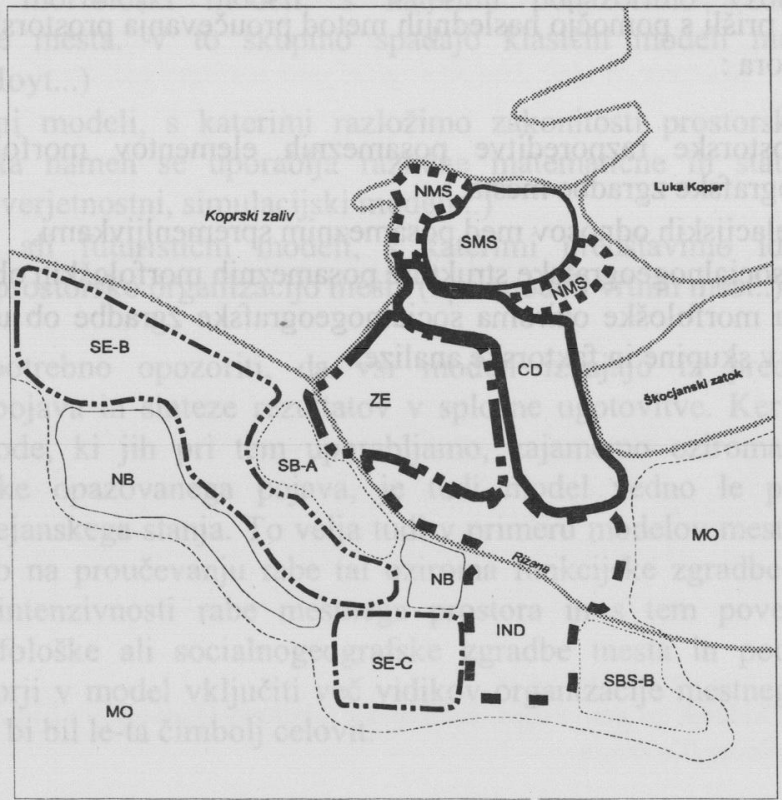


Karta 3: Ptuj - Model morfološke in socialnogeografske zgradbe

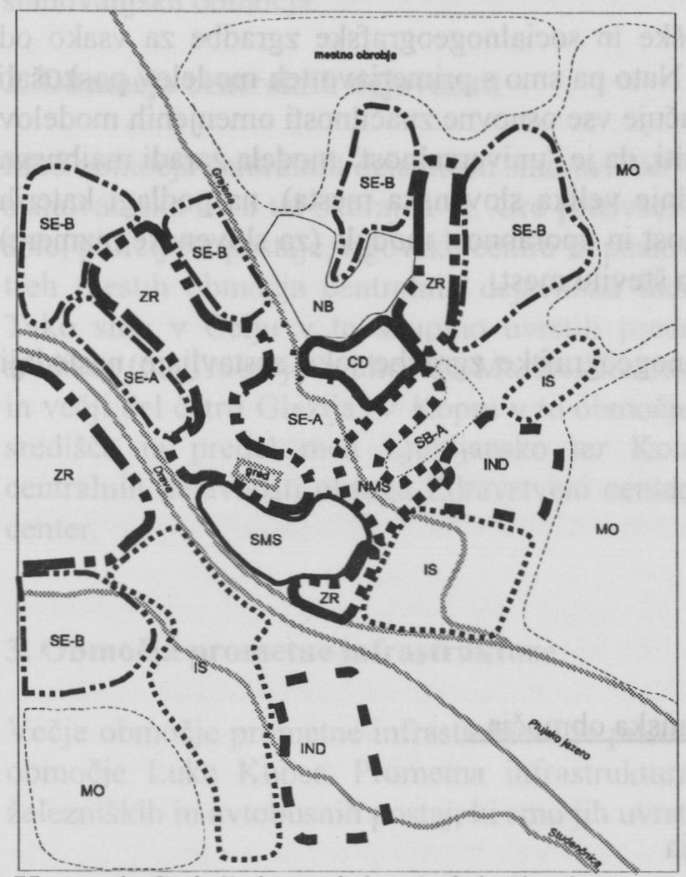

Karta 4: Splošni model morfološke in socialnogeografske zgradbe

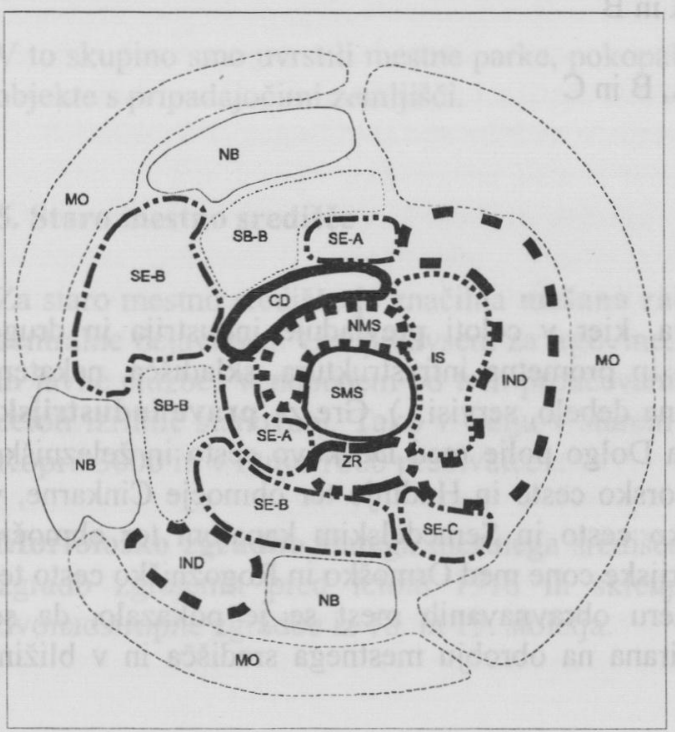

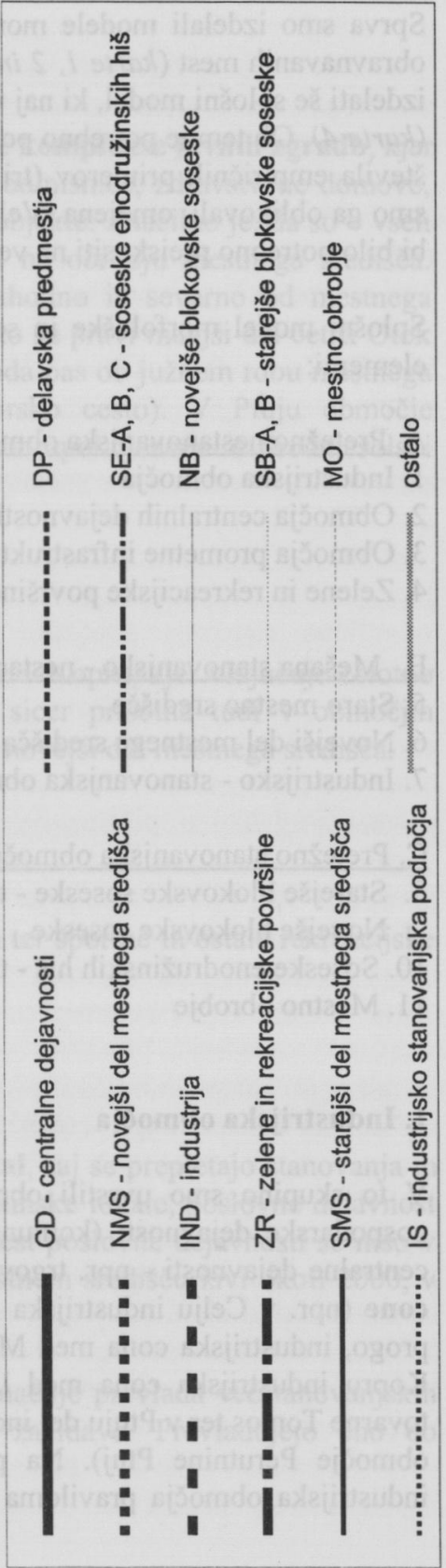


Sprva smo izdelali modele morfološke in socialnogeografske zgradbe za vsako od obravnavanih mest (karte 1, 2 in 3). Nato pa smo s primerjavo teh modelov poskušali izdelati še splošni model, ki naj vključuje vse osnovne značilnosti omenjenih modelov (karta 4). Ob tem je potrebno poudariti, da je "univerzalnost" modela zaradi majhnega števila empiričnih primerov (tri srednje velika slovenska mesta), na podlagi katerih smo ga oblikovali, omejena. Veljavnost in uporabnost modela (za slovenske razmere) bi bilo potrebno preiskusiti na večjem številu mest.

Splošni model morfološke in socialnogeografske zgradbe tako sestavljajo naslednji elementi:

\section{A. Pretežno nestanovanjska območja :}

1. Industrijska območja

2. Območja centralnih dejavnosti

3. Območja prometne infrastrukture

4. Zelene in rekreacijske površine

B. Mešana stanovanjsko - nestanovanjska območja :

5. Staro mestno središče

6. Novejši del mestnega središča

7. Industrijsko - stanovanjska območja

C. Pretežno stanovanjska območja :

8. Starejše blokovske soseske - tip A in B

9. Novejše blokovske soseske

10. Soseske enodružinskih hiš - tip A, B in C

11. Mestno obrobje

\section{Industrijska območja}

$\mathrm{V}$ to skupino smo uvrstili območja, kjer $\mathrm{v}$ celoti prevladuje industrija in druge gospodarske dejavnosti (komunalna in prometna infrastruktura, skladišča, nekatere centralne dejavnosti - npr. trgovina na debelo, servisi...). Gre za prave industrijske cone (npr. v Celju industrijska cona Dolgo polje med Dečkovo cesto in železniško progo, industrijska cona med Mariborsko cesto in Hudinjo ter območje Cinkarne, v Kopru industrijska cona med Istrsko cesto in Semedelskim kanalom ter območje tovarne Tomos ter v Ptuju del industrijske cone med Ormoško in Rogozniško cesto ter območje Perutnine Ptuj). Na primeru obravnavanih mest se je pokazalo, da so industrijska območja praviloma locirana na obrobju mestnega središča in v bližini 
železniške proge. Značilno je, da so $\mathrm{v}$ neposredni bližini industrijskih con stanovanjska območja.

\section{Območja centralnih dejavnosti}

Med območja centralnih dejavnosti smo uvrstili večje komplekse javnih zgradb, kjer stanovanjska raba tal skorajda ni. Gre predvsem za bolnišnice, zdravstvene domove, šole, policijske postaje, trgovske centre in poslovne objekte. Značilno je, da so v vseh treh mestih območja centralnih dejavnosti locirana na obrobju mestnega središča. Tako smo v Celju v to skupino uvrstili predel zahodno in severno od mestnega središča (od Trubarjeve ulice do Mariborske ceste), to se pravi manjši del četrti Otok in večji del četrti Glazija. V Kopru v to območje spada pas ob južnem robu mestnega središča in predel med Ljubljansko ter Kolodvorsko cesto). V Ptuju območje centralnih dejavnosti obsega Zdravstveni center, Dom upokojencev in Srednješolski center.

\section{Območja prometne infrastrukture}

Večje območje prometne infrastrukture je prisotno le v Kopru, kjer vključuje celotno območje Luke Koper. Prometna infrastruktura je sicer prisotna tudi v območjih železniških in avtobusnih postaj, ki smo jih uvrstili v novejši del mestnega središča.

\section{Zelene in rekreacijske površine}

V to skupino smo uvrstili mestne parke, pokopališča ter športne in ostale rekreacijske objekte s pripadajočimi zemljišči.

\section{Staro mestno središče}

Za staro mestno središče je značilna mešana raba tal, saj se prepletajo stanovanja in centralne dejavnosti. Gre predvsem za trgovine, gostinske lokale, poslovne dejavnost in javne službe. V nobenem od treh proučevanih mest poslovne dejavnosti še niso $\mathrm{v}$ celoti izrinile stanovanj. Tako v Celju v starem mestnem središču živi okoli 2000 , v Kopru 3000 in v Ptuju 1600 prebivalcev.

Morfološko zgradbo starega mestnega središča označuje prevlada večstanovanjskih zgradb zgrajenih pred letom 1918 in sklenjene zazidave. Prevladujejo eno do dvonadstropne zgradbe iz 18 . in 19. stoletja. 
Socialnogeografsko zgradbo starega mestnega središča označuje predvsem slab socioekonomski položaj in specifična starostna struktura prebivalstva ter struktura gospodinjstev. Slab socioekonomski položaj se kaže v slabi izobrazbeni strukturi (prevlada nižje izobraženih skupin prebivalstva), slabi poklicni strukturi (prevlada slabše plačanih skupin prebivalstva, predvsem storitvenih in industrijskih delavcev), slabi premoženjski strukturi, ki se kaže $\mathrm{v}$ nizkih dohodkih, visokem deležu nezaposlenih in tudi v zelo slabem stanovanjskem standardu (značilen je zelo visok delež stanovanj brez centralnega ogrevanja in stanovanj brez kopalnice). Za stara mestna središča je značilen tudi visok delež neslovenskega prebivalstva. Posebno slab socioekonomski položaj ima staro mestno središče v Ptuju, v nekoliko manjši meri pa v Celju. V Kopru so znotraj starega mestnega jedra opazne precejšne razlike. V manjšem delu starega mestnega središča je socioekonomski položaj prebivalstva precej ugodnejši (boljša izobrazbena struktura, višji dohodki, višji delež strokovnjakov...).Po vsej verjetnosti gre za tiste dele mestnega središča, ki so bili v zadnjem času obnovljeni in kot taki nudijo bistveno boljše bivanjske pogoje (predel okoli Trga Revolucije).

Drugi vidik socialnogeografske zgradbe, ki označuje staro mestno središče, pa je specifična starostna struktura prebivalstva in struktura gospodinjstev oziroma družinski status. Posebno močno izstopa visok delež samskih gospodinjstev in majhna povprečna velikost gospodinjstev, $v$ nekoliko manjši meri pa tudi nadpovprečno visok delež starejšega prebivalsta. Ob tem je zanimivo, da je tudi delež mlajšega prebivalstva relativno visok, $v$ vseh treh mestih presega povprečje za celo mesto. To lahko pripišemo dejstvu, da so se $v$ tem delu mesta zaradi nižje cene stanovanj oziroma najemnin naselile mlade družine $\mathrm{z}$ otroci. $\mathrm{Z}$ visokim deležem starejšega in pogosto samskega prebivalstva (predvsem vdove), pa je povezana tudi relativno velika stanovanjska površina na osebo. To si lahko pojasnimo s tem, da starejši prebivalci žive v relativno velikih družinskih stanovanjih, ki so jih zapustili odrasli otroci, kar lahko pojasnimo z majhno mobilnostjo starejšega prebivalstva.

\section{Novejši del mestnega središča .}

Kot posebno morfološko - socialnogeografsko območje smo izločili tisti del mestnega središča, za katerega je značilna heterogena morfološka zgradba. Tako je za ta del mesta značilno prepletanje starejših zgradb zgrajenih do leta 1918 z novejšimi stanovanjskimi bloki in stolpiči ter poslovnimi in drugimi javnimi zgradbami. Gre za nekdanje obrobje mestnega središča, ki je bilo pogosto pozidano $\mathrm{z}$ manjšimi in manj kvalitetnimi stanovanjskimi zgradbami. Tak morfološki tip je prisoten predvsem $\mathrm{v}$ Celju in v Kopru, v manjši meri pa tudi v Ptuju. Tudi za ta del mesta je značilno prepletanje centralnih dejavnosti (predvsem javne zgradbe, hoteli, trgovski in poslovni 
prostori) in stanovanj. V Celju živi v novejšem delu mestnega središča okoli 1500 , v Kopru 2300 in v Ptuju 600 prebivalcev.

Socialnogeografsko zgradbo tako omejenega območja označuje, za razliko od starega mestnega središča, relativno dober socioekonomski položaj prebivalstva, poleg tega pa še bolj izrazito kot $\mathrm{v}$ starem mestnem središču tudi prevlada starejšega prebivalstva in majhnih oziroma samskih gospodinjstev. Relativno ugoden socioekonomski položaj prebivalstva se kaže predvsem v dobri izobrazbeni strukturi (značilen je visok delež prebivalstva s srednjo oziroma višjo izobrazbo). Poklicna struktura prebivalstva ne odstopa bistveno od povprečja za celo mesto, nekoliko nadpovprečen je le delež strokovnjakov in upravnih delavcev. Tudi dohodki prebivalcev so nekoliko nadpovprečni. Iz tega lahko sklepamo, da v novejšem delu mestnega središča živi "srednji sloj". Visok delež višje izobraženih skupin prebivalstva pa kaže na koncentracijo intelektualcev v tistem delu mestnega središča, ki nudi boljše bivalne pogoje, kar se ujema $\mathrm{z}$ ugotovitvami večine sorodnih raziskav za zahodnoevropska mesta. Družinski status prebivalstva označuje majhna povprečna velikost gospodinjstev in visok delež samskih gospodinjstev ter nadpovprečen delež starejšega prebivalstva. Za ta del mesta so torej značilna majhna, pogosto samska in ostarela gospodinjstva. Tudi to dejstvo se ujema $\mathrm{z}$ ugotovitvami socialno - ekoloških raziskav.

\section{Industrijsko - stanovanjska območja}

Tretji morfološko - socialnogeografski tip, za katerega je značilno prepletanje stanovanjske in nestanovanjske rabe tal so industrijsko - stanovanjska območja. Povečini gre za starejše industrijske predele, kjer je poleg industrijskih objektov, skladišč in prometne infrastrukture tudi nekaj stanovanjskih zgradb. V Celju lahko govorimo o pravem delavskem predmestju (Gaberje), saj so bile stanovanjske zgradbe za delavce ob koncu 19. in $\mathrm{v}$ začetku 20. stoletja zgrajene skupaj $\mathrm{z}$ industrijskimi objekti, na kar kažejo tudi imena ulic v tem delu mesta (Tovarniška, Delavska, Kovinarska, Cinkarniška). Povečini gre za manjše večstanovanjske zgradbe v sklenjeni zazidavi. V industrijsko - stanovanjskih predmestjih Zavodna in Čret pa prevladujejo eno do dvostanovanjske hiše slabše kvalitete. V to skupino smo uvrstili tudi staro celjsko predmestje Breg. V Kopru takšnega morfološko socialnogeografskega območja zaradi specifičnega urbanističnega in gospodarskega razvoja mesta ni. V Ptuju je tipično delavsko predmestje $\mathrm{z}$ zgoraj naštetimi značilnostmi Breg na desnem bregu Drave ter novejši predel ob Rogozniški in Ormoški cesti.

Za industrijsko - stanovanjska območja so značilne zelo slabe ekološke in bivalne razmere (na kar kaže tudi zelo slab stanovanjski standard - delež stanovanj brez kopalnice dosega $30 \%$, brez centralnega ogrevanja pa $70 \%$ ), splošna zanemarjenost 
$\mathrm{Za}$ industrijsko - stanovanjska območja so značilne zelo slabe ekološke in bivalne razmere (na kar kaže tudi zelo slab stanovanjski standard - delež stanovanj brez kopalnice dosega $30 \%$, brez centralnega ogrevanja pa $70 \%$ ), splošna zanemarjenost in slaba kvaliteta zgradb. Vse to skupaj, z izrazito neugodno socialnogeografsko zgradbo, kaže na začetek socialne "getoizacije". V tako omejenih območjih živi v Celju okoli 1700, v Ptuju pa 900 prebivalcev.

Izrazito neugodna socialnogeografska zgradba je razvidna iz zelo slabe izobrazbene strukture prebivalstva (delež prebivalcev $\mathrm{z}$ nižjo izobrazbo praviloma presega $50 \%$ ), neugodne poklicne strukture (prevlada industrijskih in storitvenih delavcev), nizkih dohodkov prebivalstva (dohodnina na prebivalca dosega le okoli 75 $\%$ vrednosti za celo mesto) in visokega deleža nezaposlenih. Družinski status prebivalstva pa označuje prevlada majhnih oziroma samskih gospodinjstev. V povezavi z visokim deležem neslovenskega prebivalstva (v Celju skoraj $30 \%$ in na Bregu v Ptuju okoli 20 \%) lahko sklepamo, da je za ta del mesta značilnen visok delež priseljencev iz bivših republik Jugoslavije. Prevladujejo moški, ostali del družine je ostal "doma". Značilen je tudi posebno visok delež Albancev in Muslimanov ter relativno nižji delež Hrvatov in Srbov. Gre za specifično socialno skupino, za katero je značilen izrazito slab socioekonomski položaj, še posebno izstopa visoka nezaposlenost.

\section{Starejše blokovske soseske - tip A in B}

Med starejše blokovske soseske smo uvrstili območja, kjer prevladujejo stanovanjski bloki zgrajeni med leti 1946 in 1970. Povečini gre za štirinadstropne, prostostoječe bloke, v manjši meri tudi za posamezne višje stanovanjske stolpiče. V večini primerov ne moremo govoriti o pravih blokovskih soseskah z vso pripadajočo družbeno infrastrukturo (šola, oskrba, rekreacijske površine itd.), temveč bolj o skupinah večstanovanjskih zgradb. V starejših blokovskih soseskah živi v Celju okoli 9000, v Kopru 4000 in v Ptuju 1500 prebivalcev.

Tako določen morfološki tip pa smo na podlagi razlik v socialnogeografski zgradbi ločili na dve morfološko - socialnogeografski območji. Za tip A je značilen ugodnejši socioekonomski položaj prebivalstva. Ta se kaže $v$ relativno ugodni izobrazbeni strukturi, predvsem v visokem deležu prebivalcev s srednjo izobrazbo. Za poklicno strukturo je značilen nadpovprečen delež strokovnjakov in upravnih delavcev. 
Družinski status prebivalstva označuje predvsem nizek delež mlajšega prebivalstva, relativno majhna gospodinjstva, $v$ manjši meri pa tudi nadpovprečen delež starejšega prebivalstva. Iz tega lahko sklepamo, da $v$ tem delu mesta prevladujejo gospodinjstva srednje generacije. To lahko pojasnimo $\mathrm{z}$ dejstvom, da so ob izgradnji stanovanja kupile mlade družine, ki pa so se medtem postarale. Tudi ta proces je povezan tudi z majhno mobilnostjo prebivalcev v Sloveniji. Na splošno lahko rečemo, da po svoji socialnogeografski zgradbi starejše blokovske soseske tipa A v mnogočem spominjajo na novejši del mestnega središča, kar je prav gotovo povezano tudi z dejstvom, da so locirane v neposredni bližni mestnega središča.

Tip B starejših blokovskih sosesk se od tipa A loči po svoji socialnogeografski zgradbi, predvsem po socioekonomskem položaju prebivalstva, ki je nekoliko manj ugoden. Na splošno lahko rečemo, da socialnogeografska zgradba tega dela mesta ne odstopa od mestnega povprečja.

\section{Novejše blokovske soseske}

V to morfološko - socialnogeografsko območje smo uvrstili blokovske soseske zgrajene po letu 1971. Večinoma gre za večje soseske s spremljajočo družbeno infrastrkturo (šola, vrtec, oskrba, rekreacija...). Primer takšnih sosesk so npr. deli sosesk Zgornja Hudinja, Nova vas in Lava v Celju, soseska Podmarkovec v Kopru in del soseske Rabelčja vas v Ptuju. V novejših blokovskih soseskah živi v Celju okoli 15000, v Kopru 9000 in v Ptuju 5000 prebivalcev.

Socialnogeografsko zgradbo novejših blokovskih sosesk označuje predvsem specifična starostna struktura prebivalstva in struktura gospodinjstev. Tako ti deli mesta izstopajo po zelo visokem deležu mladega prebivalstva, nizkem deležu starejšega prebivalstva in velikih gospodinjstvih. Vse to kaže na prevlado mladih družin z otroci. Značilno je, da le-te žive $v$ relativno majhnih stanovanjih, na kar kaže majhna stanovanjska površina na osebo (pod $15 \mathrm{~m} 2$, v soseski Lava v Celju celo pod $10 \mathrm{~m} 2)$. $\mathrm{Za}$ socioekonomski položaj prebivalstva tega morfološko socialnogeografskega območja je značilno, da je relativno neugoden, čeprav precej boljši kot v starem mestnem središču ali stanovanjsko - industrijskih območjih. Izobrazbeno strukturo prebivalstva označuje nekoliko nadpovprečen delež prebivalcev $\mathrm{z}$ nižjo izobrazbo, poklicno strukturo pa visok delež industrijskih delavcev. Tudi dohodki prebivalcev so nekoliko podpovprečni (dohodnina na prebivalca dosega približno $95 \%$ vrednosti za celo mesto). Pri tem pa je potrebno opozoriti, da so med posameznimi soseskami in tudi znotraj sosesk glede socioekonomskega položaja prebivalstva precejšne razlike. Naslednja značilnost tega območja je nadpovprečen delež neslovenskega prebivalstva, ki v Celju dosega med 20 in $25 \%$, v Kopru med 30 in $35 \%$ ter v Ptuju okoli $10 \%$ prebivalstva. Predvidevamo, da gre ta tisti del 
neslovenskega prebivalstva, ki se je v Sloveniji "ustalil" in ustvaril družine. Ob tem je potrebno povdariti, da kljub nekoliko nižjemu deležu kot $v$ starem mestnem središču oziroma industrijsko - stanovanjskih območjih, v novejših blokovskih soseskah živi večji del neslovenskega prebivalstva ( $v$ Celju približno 3500 od skupaj 7500 in v Kopru 3000 od skupaj 7000).

\section{Soseske enodružinskih hiš - tip A, B in C}

Soseske enodružinskih hiš, za katere je značilna strnjena nesklenjena zazidava in prevlada eno oziroma dvostanovanjskih hiš, smo glede na razlike v socialnogeografski zgradbi razdelili $v$ tri tipe.

Tip A vključuje predvsem starejše soseske enodružinskih hiš, ki so praviloma locirane blizu mestnega središča. Značino je, da so te soseske začeli graditi že ob začetku stoletja. Glede na starost stanovanj so zato precej heterogene (stanovanja so deloma iz obdobja pred letom 1918, deloma iz časa med obema vojnama in deloma iz prvega povojnega obdobja). V večini primerov gre za območja z meščanskimi vilami, $v$ katerih je pred drugo svetovno vojno živel višji in srednji sloj prebivalstva. Opraviti imamo torej z tradicionalnimi elitnimi deli mesta. Med soseske enodružinskih hiš tipa A smo v Celju uvrstili del četrti Otok, sosesko Aljažev hrib, območje med Oblakovo ulico in železniško progo in osrednji del soseske Polule. V Ptuju v to skupino spadajo soseska Vičava in območje enodružinskih hiš med Maistrovo in Raičevo ulico ter Volkmerjevo cesto). V Kopru takšnega morfološko - socialnogeografskega tipa nismo določili.

Socialnogeografsko zgradbo tega dela mesta označujeta dve potezi : dober socioekonomski položaj prebivalstva in prevlada starejših ter manjših gospodinjstev. Dober socioekonomski položaj je razviden predvsem iz dobre izobrazbene strukture (delež prebivalcev z višjo izobrazbo praviloma presega $10 \%$ ). Pri poklicni strukturi izstopa visok delež strokovnjakov in vodilnih delavcev. Tudi dohodki prebivalcev so nadpovprečno visoki. Za družinski status pa je značilna prevlada starejših gospodinjstev in gospodinjstev srednje generacije. Razmeroma visok je tudi delež samskih gospodinjstev. Etnično strukturo zaznamuje nizek delež neslovenskega prebivalstva.

V tip B smo uvrstili večino preostalih sosesk enodružinskih hiš, za katere je značilno, da so bile zgrajene v povojnem obdobju. V času med leti 1946 in 1970 so bile zgrajene soseske enodružinskih hiš Zgornja Hudinja, Medlog in deloma Polule ter Zagrad v Celju, Semedela in deloma Žusterna ter Olmo v Kopru in soseska Štuki v Ptuju, po letu 1971 pa soseske enodružinskih hiš Lava, Ostrožno in Nova vas v Celju, Žusterna v Kopru in Nova vas, Orešje ter Rabelčja vas v Ptuju. Za zgoraj naštete 
novejše soseske enodružinskih hiš je značilno, da imajo najugodnejšo socioekonomsko sestavo prebivalstva od vseh območij. Ta se kaže v dobri izobrazbeni strukturi, visokem deležu strokovnjakov in vodilnih delavcev, visokih dohodkih prebivalcev (dohodnina na prebivalca dosega v Celju 130, v Kopru 140 in v Ptuju $120 \%$ vrednosti za celo mesto). Poleg tega je za novejše soseske enodružinskih hiš značilen nizek delež nezaposlenih in neslovenskega prebivalstva, prav tako pa tudi najugodnejši stanovanjski standard (stanovanjska površina na prebivalca dosega okoli $30 \mathrm{~m} 2$, delež stanovanj brez centralnega ogrevanja in stanovanj brez kopalnice pa je nizek). Podrobnejši pregled socioekonomskega položaja prebivalstva po posameznih soseskah pokaže, da je le-ta najugodnejši v soseskah zgrajenih po letu 1971 (npr. Lava in Ostrožno in Nova vas v Celju, del Semedele v Kopru in deli sosesk Orešje in Nova vas v Ptuju). Družinski status tega morfološko - socialnogeografskega območja ne odstopa bistveno od mestnega povprečja. Značilna je prevlada gospodinjstev srednje generacije in nizek delež samskih gospodinjstev. Iz podpovprečnega deleža prebivalstva do 18 leta starosti lahko sklepamo, da je delež mladih družin z otroci nizek. To pomeni, da si večina mladih družin ne more privoščiti "hiše z vrtom".

V tip C sosesk enodružinskih hiš smo uvrstili sosesko Podgorje v Celju in sosesko Olmo v Kopru, ki odstopata po slabem socioekonomskem položaju prebivalstva. Pri tem je potrebno povdariti, da se ti dve soseski precej razlikujeta.

Soseska Podgorje v Celju je primer soseske črnih gradenj. Gre za enodružinske hiše slabše kvalitete. Soseska se nahaja v delu mesta s slabimi ekološkimi razmerami (nad Celjsko Cinkarno) in močno degradiranim okoljem. V celoti daje ta del mesta vtis precejšnje neurejenosti. Socialnogeografsko zgradbo te soseske označuje izrazito slab socioekonomski položaj prebivacev, visok delež neslovenskega prebivalstva in prevlada velikih in mlajših gospodinjstev. Slab socioekonomski položaj se kaže v zelo slabi izobrazbeni strukturi prebivalstva (delež prebivalcev z nižjo izobrazbo dosega 60 $\%$ ), prevladi industrijskih delavcev (nad $50 \%$ ), nizkih dohodkih prebivalstva (dohodnina na prebivalca dosega le $65 \%$ vrednosti za celo mesto) in visokem deležu nezaposlenih. Delež neslovenskega prebivalstva dosega $40 \%$. Zelo slab je tudi stanovanjski standard, ki se kaže v majhni stanovanjski površini na osebo (pod $20 \mathrm{~m} 2$ ) in visokem deležu stanovanj brez centralnega ogrevanja ter stanovanj brez kopalnice. Za družinski status je značilna prevlada velikih ter mlajših gospodinjstev oziroma gospodinjstev srednje generacije. Gre torej za socialno zelo problematični del mesta, pri katerem bi lahko govorili o začetku "getoizacije".

Večji del soseske Olmo obsega manjše vrstne enodružinske hiše v neposredni bližini tovarne Tomos. Po socialnogeografski zgradbi, za katero je značilen podpovprečen, vendar ne izrazito slab socioekonmoski položaj prebivalcev, ta soseska spominja na starejše blokovske soseske tipa B (npr. Nova Šalara v Kopru). Predvsem izstopa slaba izobrazbena struktura in visok delež industrijskih delavcev, dočim dohodki 
prebivalcev niso dosti nižji od mestnega povprečja. Za stanovanjski standard je značilna predvsem nizka stanovanjska površina na osebo (pod $20 \mathrm{~m} 2$ ). Družinski status pa označuje prevlada nadpovprečno velikih gospodinjstev mlajše in srednje generacije.

\section{Mestno obrobje}

V morfološko - socialnogeografski tip mestno obrobje smo uvrstili območja na robu mesta, za katera je značilna redkejša oziroma nestrnjena zazidava. V celoti prevladujejo prostostoječe enodružinske hiše. Poleg stanovanjskih območij velik del ozemlja obsegajo agrarne površine in gozd. Zato je tudi gostota prebivalstva $\mathrm{v}$ tem delu mesta za urbana območja zelo nizka, saj praviloma ne presega 2 preb./ha.

V mestno obrobje so vključena predvsem nekoč samostojna ruralna naselja, ki pa so bila $s$ širjenjem mesta vključena $v$ urbano območje. $V$ središču teh naselij so stara vaška jedra $\mathrm{z}$ značilno vaško fiziognomijo (kmečke hiše in gospodarska poslopja, nepravilen tloris prometnic). Na obrobju, pa tudi med starejšimi zgradbami, je prišlo tudi do novejše gradnje enodružinskih hiš. To je razvidno iz podatkov o strukturi stanovanj po obdobju gradje (približno ena četrtina do leta 1918, četrtina med leti 1946 in 1970 in tretjina po letu 1971). Značilno je, da so ta naselja med seboj ločena z vmesnimi nepozidanimi površinami (agrarne površine ali gozd). V to skupino lahko v Celju uvrstimo obmestna naselja Spodnja Hudinja, Trnovlje, starejši del Zgornje Hudinje, Lopata, Babno in Ložnica, v Kopru Škocjan in v Ptuju obmestna naselja Spuhlja, Budina, Brstje, Rogoznica, del Spodnje Hajdine in Turnišče. Kot poseben tip mestnega obrobja pa bi lahko izločili območja $\mathrm{z}$ razloženo oziroma nesklenjeno zazidavo in zelo nizko gostoto prebivalstva (okoli 1 preb./ha). Gre predvsem za gričevnato oziroma hribovito obrobje mesta, kjer večji del površin zavzema gozd. V to skupino smo uvrstili Lisce, Miklavžev hrib, Stari grad in Zavodno v Celju, Markovec v Kopru in Mestni vrh v Ptuju.

Mestno obrobje ima zelo specifično socialnogeografsko zgradbo. Socioekonomski položaj prebivalstva, ki je relativno slab, označuje predvsem visok delež kmetijskih delavcev ( v Celju 12, v Kopru 8 in v Ptuju $16 \%$ aktivnega prebivalstva), ki je v ostalih delih mesta zelo nizek (pod $1 \%$ ). To kaže na polruralni značaj tega dela mesta. Najvišji delež sicer odpade na industrijske delavce (med 40 in $50 \%$ ). Značilna je tudi zelo slaba izobrazbena struktura (delež prebivalcev z nižjo izobrazbo presega $50 \%$ ) in podpovprečni dohodki prebivalcev (vendar ne izrazito nizki, dohodnina na prebivalca dosega okoli $90 \%$ mestnega povprečja). $\mathrm{V}$ primeru Celja in Ptuja močno izstopa tudi nizek delež neslovenskega prebivalstva (7 oziroma $6 \%$ ) in nizek delež nezaposlenih. Družinski status tega območja označuje prevlada velikih gospodinjstev. Starostna 
struktura pa kaže na enakomerno zastopanost vseh starostnih skupin prebivalstva. Iz tega lahko sklepamo, da so $\mathrm{v}$ tem delu mesta pogosta takoimenovana generacijska gospodinjstva, ki jih sestavljajo stari starši, starši in otroci.

\section{ZAKLJUČEK}

Osnovno izhodišče našega raziskovanja je bilo, da je tudi v slovenskih mestih prisotna diferenciacija mestnega prostora glede na morfološko in socialnogeografsko zgradbo.. Nadalje smo predvidevali, da obstaja med morfološko in socialnogeografsko zgradbo mesta določena povezanost in soodvisnost.

Obe zastavljeni delovni hipotezi lahko na podlagi opravljenih analiz in sintezi le-teh v model morfološke in socialnogeografske zgradbe potrdimo. Iz opisanega modela je namreč razvidno, da je prostorska socialna diferenciacija mestega prebivalstva prisotna tudi $v$ slovenskih mestih. Primerjava s sorodnimi študijami pokaže, da je stopnja te diferenciacije primerljiva $\mathrm{z}$ razmerami $\mathrm{v}$ manjših in srednjevelikih zahodnoevropskih mestih.

Potrdimo lahko tudi obstoj povezave med morfološko in socialnogeografsko zgradbo mesta. Tako je za določen morfološki tip mesta praviloma značilna specifična socialnogeografska zgradba. Ob tem je potrebno opozoriti, da "ujemanje" med obema vidikoma notranje zgradbe mesta, nikakor ni popolno. Tako so znotraj podobnih morfoloških območij (npr. soseske enodružinskih hiš ali blokovske soseske) precejšnje razlike v socialni sestavi prebivalstva, po drugi strani pa imajo nekatera povsem različna morfološka območja (npr. novejši del mestnega središča in blokovske soseske) določene skupne poteze.

Iz rezultatov naše raziskave lahko zaključimo, da socialnogeografsko zgradbo slovenskih mest sestavljata dva osnovna elementa : socioekonomska in družinska diferenciacija prebivalstva. Pri tem socioekonomsko difereciacijo določajo predvsem izobrazbena, poklicna in premoženjska struktura, družinsko pa struktura gospodinjstev in starostna struktura prebivalstva. Etnična sestava prebivalstva se sicer po posameznih delih mesta pomembno razlikuje, vendar ne $\mathrm{v}$ takšni meri, da bi samostojno določala oziroma označevala posamezne dele mesta. Ena izmed osnovnih ugotovitev faktorske ekologije je tudi dejstvo, da prostorska razporeditev posameznih skupnih faktorjev (socioekonomski, družinski in etnični status), sledi določenim zakonitostim. Tako je socioekonomski faktor razporejen sektorsko, družinski koncentrično in etnični večjedrno. To velja tudi v primeru Celja in Ptuja, v manjši meri pa v primeru Kopra. Območja z dobrim socioekonomski položajem so v Celju in Ptuju razporejena v obliki krakov oziroma sektorjev (npr. Otok-Medlog, Dolgo polje- 
Nova vas, Lava-Ostrožno, Aljažev hrib-Polule-Zagrad, Rabeljčja vas-Nova vas, Vičava--Orešje). Med njimi so območja s slabim oziroma povprečnim socioekonomskim položajem. Družinski status pa je razporejen v obliki koncentričnih krogov, ki se od mestnega središča širijo proti obrobju mesta. Tako je za notranja območja bliže mestnemu središču značilna prevlada majhnih in samskih gospodinjstev, starejšega prebivalstva in stanovanj v večstanovanjskih hišah. Proti obrobju mesta pa se povečuje povprečna velikost gospodinjstev, delež mladega prebivalstva in delež stanovanj $v$ enodružinskih hišah. Etnični status, ki je deloma prisoten le v Celju, ima dejansko več "središč" z visokimi vrednostmi (mestno središče, Gaberje, novejše blokovske soseske), tako da bi lahko govorili o večjederni prostorski razporeditvi. Kot je bilo rečeno, so v primeru Kopra opisani vzorci prostorske razporeditve manj očitni, kar je po vsej verjetnosti predvsem posledica specifičnih reliefnih razmer in urbanističnega razvoja mesta.

\section{LITERATURA}

- Bašić K.,1994 : Socijalno-prostorna segregacija stanovništva Zagreba. Geografski Horizont, broj 2, Godina XL, Zagreb.

- Bailly A., Beaudry M.,1976 : Analyse typologiques en milieu urbain : Les aires homogenes d'Edmonton (Canada). L'Espace géographiques, no.4, str. 267-275, Paris.

- Beaujeu-Garnier J., 1980 : Géographie urbaine. Armand Collin, Paris.

- Berger M., Debol-Kritter A., 1989 : Das Ortsbild von Augsburg. Angewandte Socialgeographie Beitrage, no. 19, Universität Augsburg.

- Drozg V., 1995 : Morfologija vaških naselij v Sloveniji. Geographica Slovenica 27, Ljubljana.

- Drozg V., 1990 : Členitev mestnega območja Izole, 15. Zborovanje slovenskih geografov. Portorož. Zveza geografskih društev Slovenije, Ljubljana.

- Geographia Polonica - The Urban Population at a Microscale, 1993. Polish Academy of Sciences, Institute of Geography and Spatial Organization, Warszawa.

- Hamm B., 1984 : Aktuelle Probleme sozialekölogischer Analyse. Koelner Zeitschrift fur Sociologie und Socialpsychologie, 36, 2.

- Klemenčič M. M., 1993 : Narodnostna in starostna sestava prebivalcev Tržiča, Geografski vestnik, 65, str. 79-90, Ljubljana.

- Klinar P., 1986 : Problematika medetničnih odnosov. RI FSPN. Ljubljana.

- Loboda J., 1989 : Ausgewählte Probleme der räumlichen Gliederung Wroclaws. Geographische Zeitschrift, 77. Jahrhang, Heft 4. 
- Lentz S., 1991 : Strukturraumanalyse und Stadtmodele. Überlegungen zu neuen Arbeitsansatzen am Beispiel der Stadt Mannhein. Studien zur Bevölkerungs- und Sozialgeographie, Mannheimer Geographischer Arbeiten, Mannheim.

- Maribor - Marburg, 1994 : Prispevek h geografiji prijateljskih mest. Maribor.

- Pak M., 1987 : Problematika izrabe mestnega prostora v Mariboru. Zbornik žII. kongresa geografa Jugoslavije u Vojvodini - 1985, Novi Sad.

- Pak M. , 1991 : Elementi demografskega razvoja v zgradbi Maribora. Dela 8, Ljubljana.

- Rebernik D., 1996 : Morfološka in socialnogeografska zgradba slovenskih mest (na izbranih primerih). Magistrska naloga, Oddelek za geografijo Filozofske fakultete v Ljubljani

- Schaffer F., Guttler H., 1982 : Sozialtopographie der Altstadt. Angewandete Sozialgeographie Beitrage, no. 4, Universität Augsburg.

- Seger M., Wastl-Walter D., 1991 : Die Socialistische Stadt in Mitteleuropa. Der Modellfall Halle a.d. Salle. Zustand und Struktur am Ende einer Epoche. Geographische Rundschau.

- Seger M., 1988 : Die Stadtstrucktur von Villach - Eine statistische Analyse nach Zahlbezircken. Stadt und Umwelt - Arbeiten zum Grünraumsituation in Villach. Villach.

- Toš N., 1986 : Socialna struktura sodobne slovenske družbe. RI FSPN, Ljubljana. 


\section{A MODEL OF MORPHOLOGICAL AND SOCIOGEOGRAPHICAL STRUCTURE OF URBAN SPACE STUDIED AT CELJE, KOPER AND PTUJ}

\section{Summary}

A basic premise of our investigation is that differentiation of urban space as to the morphological and sociogeographical structures is also present in Slovenian towns. Next, we assume that certain connectedness and interdependence exist between the morphological and sociogeographical structures of town.

Both working hypotheses can be confirmed on the basis of performed analyses and their synthesis into a model of morphological and sociogeographical structures. Namely, it is evident from the described model that the spatial social differentiation of urban population is present in Slovenian towns, too. A comparison with similar studies shows that the level of this differentiation is comparable to the conditions in minor and medium-sized western-European towns.

The existence of links between morphological and sociogeographical structures of town can also be confirmed. Thus, typical of a certain morphological type of town, as a rule, is the specific sociogeographical structure. On this point, attention should be called to the fact that the parallelism of both aspects of the inner structure of town is not perfect at all. Thus, within similar morphological areas (e.g. detached house districts or apartment house districts) rather great differences are evident in the social structure of the population, while on the other hand, certain areas which are morphologically totally different (e.g. newer parts of inner city and apartment house districts) have the common features.

We can conclude from the results of our investigation that the sociogeographical structure of Slovenian towns consists of two basic elements: the socioeconomic differentiation and the family differentiation of the population. Socioeconomic differentiation is determined especially by the educational, vocational and wealthrelated structures, while the family differentiation is determined by the structure of households and the age structure of the population. Although ethnic composition of the population significantly differs in the individual parts of town, yet, this differentiation is not so typical that it could determine or mark the individual parts of town.

Among the basic findings of factors' ecology is undoubtedly ranked the fact that the spatial distribution of individual common factors (socioeconomic, ethnic and the family status) is subject to certain laws. Thus, the socioeconomic factor is distributed 
in sectors, the family factor is distributed concentrically, and the ethnic factor occurs as the multicore distribution. This also applies to Celje and Ptuj, and in a smaller extent, to Koper. The areas of favourable socioeconomic position in Celje and Ptuj are distributed in the form of branches or sectors (e.g. Otok-Medlog, Dolgo polje-Nova vas, Lava-Ostrožno, Aljažev hrib-Polule-Zagrad, Rabeljčja vas-Nova vas, VičavaOrešje). In between them are the areas of poor or average socioeconomic position.

The family status is distributed in the form of concentric circles, which spread outwards from the town core to the suburbs. Thus, the inner areas which are closer to the town core, are typical of prevailing small or single households, elderly population and the apartment house housing. Towards the suburbs, the following factors increase: the average size of households, the percentage of young population, and the percentage of detached house housing. Ethnic status which is partly present only at Celje, has several "centers", in fact, with high values (the inner city, Gaberje, newer apartment house districts) so that it could be defined as the multicore spatial distribution. As mentioned above, the described examples of spatial distribution are less evident in Koper, which is most probably the result of specific conditions as to the landforms, and the town planning of Koper. 